Article

\title{
Tourist Renewal as a Strategy to Improve the Competitiveness of an Urban Tourist Space: A Case Study in Maspalomas-Costa Canaria
}

\author{
José M. Sanabria Díaz ${ }^{1, * \mathbb{D}}$, Teresa Aguiar Quintana ${ }^{2}$ and Yazmina Araujo Cabrera ${ }^{2, *}$ \\ 1 Department of Public Law, University of Las Palmas de Gran Canaria, \\ 35017 Las Palmas de Gran Canaria, Spain \\ 2 Department of Tourism, Economy and Management, University of Las Palmas de Gran Canaria, \\ 35017 Las Palmas de Gran Canaria, Spain; teresa.aguiar@ulpgc.es \\ * Correspondence: jose.sanabria@ulpgc.es (J.M.S.D.); yazminagloria.araujo@ulpgc.es (Y.A.C.)
}

Received: 4 September 2020; Accepted: 11 October 2020; Published: 22 October 2020

\begin{abstract}
The reclassification of accommodation for tourism, understood as the change of tourist category or classification in terms of accommodation activity, is put forward as one of the ways to increase competitiveness in any establishment. So, recent regulation on planning, renovation and modernization of Tourism in Canary Islands established the need to increase the classification of the accommodation offering by restoring degraded tourist areas and renovating different public and private infrastructures. Using a case study methodology in this paper, the characteristics of the rehabilitation process undertaken in different touristic establishments of the coast of Gran Canaria, are analyzed, more specifically in Maspalomas-Costa Canaria destination. Comparative analysis of these cases presenting it as a rehabilitation model that allowed it to re-join the market, benefiting from the urban incentives policies through the upgrading strategy, increasing the quality and quantity of the services offered.
\end{abstract}

Keywords: tourism facilities; renovation; competitiveness; urban planning; density; obsolescence

\section{Introduction}

The different types of tourist accommodation are one of the essential bases on which the activity of travelers during their stay in any destination is based. The low seasonal variations of the Canary Islands archipelago greatly conditioned the fact that the Canary Islands was consistently the main destination with the greatest weight in tourist expenditure in Spain (February 2020), with $30.1 \%$ of the total, followed by Catalonia (20.7\%), Andalusia and the Community of Madrid (both with $13.9 \%$ ). If this element is broken down, in relation to expenditure not included in tourist packages (3817 million euros), $17.55 \%$ was allocated to the accommodation heading in 2019 (EGATUR, February 2020).

In the same proportion, in mature destinations, the obsolescence of the accommodation infrastructure (functional, in terms of the business model, organizational, physical, technological, etc.) is a weakening item of the necessary competitiveness, arising from an old fashioned situation that can be corrected through more ambitious interventions than simple aesthetic modernization, "lifting" or make-up actions [1,2] performed on less durable elements (systems, floors, finishes, interior carpentry, etc.), but which do not solve the establishment's problems in such a dynamic and versatile market, that forces to keep up with the highest demands of competitiveness.

Based on the above, this article's main objective is to analyze the renovation process undertaken in different touristic establishments of principal touristic Municipality in Gran Canaria that is San Bartolomé de Tirajana. 
The process developed is approached by taking into consideration the different circumstances of urban planning that are recorded in the file, in addition to the upgrading strategy of the different areas of the establishment to proceed to its reclassification and the capture of other market segments, identifying the results obtained in different quantitative (prices, occupancy, yield, etc.), positioning (category, classification, rankings, etc.) and marketing (sales channels used) items once the rehabilitation process is concluded.

Vera-Rebollo [3] Simancas and Ledesma [4], Dorta [5] and Sanabria, Simancas and Aguiar [6] consider that building renovation processes in mature tourist destinations imply the need to redefine and update the concepts used on this matter, which have traditionally referred to residential areas but which in the field of tourist involves a triple vision; physical, territorial and economic.

Based on this, the specific objectives of this research are: (1) Studying the tourism renewal process in different types of tourist accommodation, and (2) looking at the different magnitudes of profitability, positioning and prestige of the analyzed tourist accommodation after the renovations undertaken that enables projection of the data obtained to the rest of the universe of interest (obsolete tourist areas with different types of accommodation in other tourist mature destinations). Case study methodology has been used in order to achieve these objectives in 5 touristic establishments, representative of San Bartolomé de Tirajana accommodation touristic offer and as undertaken renovation process models and results obtained, using different planning incentives.

In order to establish a consistent and progressive process in the research, the following stages are addressed consecutively: (1) Review of the regulations on which Law 2/2013 of 29 May on Tourist Renewal and Modernization is based, (2) study of the 17 administrative proceeding opened at the San Bartolomé de Tirajana City Council under the Plan for Modernization, Improvement and Increase in Competitiveness of Maspalomas Costa Canaria, exclusively with regard to interventions in private space; (3) selection of 5 of the models offered by the different case studies analyzed and characterization of the implementation of the Modernization Plans in the San Bartolomé de Tirajana tourist accommodation offering; (4) analysis of the information obtained from both the specific project documentation, the administrative enquiry and other sources that may provide information on both the project undertaken and the results obtained; and (5) presentation of the results, conclusions, contributions as well as limitations and future lines of research.

\section{Literature Review}

\subsection{Regulatory Context}

The modernization and interventions of rehabilitation and renovation of tourist accommodation has become one of the structural axes of tourism policy in the Autonomous Region of the Canary Islands; essentially from the approval of the Organic Law 10/1982 of 10 August on the Statute of Autonomy amending the competence area in territorial planning, urban planning and housing, as well as development and planning of tourism in the Canary Islands (Art. 29, Sections 11 and 14 respectively).

From that moment on, the Autonomous Community takes the lead in the drift of its territory from a regulatory point of view, completing the planning task it was entrusted with [7]. This restructuring policy has been highlighted by several authors such as Mirallave [8], García Márquez [9], Llorca and Sosa [10], Risueño [11], Simancas [2,12,13], Villar, Temes-Cordovez [14] and Rodríguez and Santana [15], and has been articulated around two different moments in time: (a) That initiated in the context of the so-called "tourism moratorium" which was regulated by Decree 4/2001 whereby the formulation of the General Planning and Tourism Guidelines were agreed and consolidated with Law 19/2003 which approved them; and (b) that undertaken with the enactment of Law 6/2009 on Urgent Measures in Terms of Territorial Planning for the Sector's Revitalization and Tourism Planning, which partially modified it and was replaced by Law 2/2013 on the Renewal and Modernization of Tourism in the Canary Islands, amended by the current Law 9/2015. 
The Partial Plans that allowed the construction of the different tourist destinations in the Canary Islands were initially an exception in the planning system of the Canary Islands, brought about by the entanglement of territorial regulations that explained the search for unique instruments [16].

Subsequently, and from a perspective of tourism governance which is set up as an essential descriptive and analytical tool for the governance of tourism [17-23], the Modernization, Improvement and Increasing Competitiveness Plans (PMMs) were, up until the time they were cancelled by the Supreme Court, effective instruments for enforcing renewal policies in a mature tourist destination such as San Bartolomé de Tirajana. Until then, the General Urban Planning Plans could be amended and even moved by the PMMs, effectively overlapping in the territorial planning of tourist areas, which meant a legal "shortcut" and unblocking of the Urban Development Plans, thus violating the distribution of competences established in the Revized Text of the Laws of Territorial Planning of the Canary Islands and Natural Areas of the Canary Islands, and as was made clear in the subsequent rulings of the Supreme Court on the PMMs.

Maspalomas-Costa Canaria urbanization in the municipality of San Bartolomé de Tirajana, was designed by the French consortium AS ATEA+SETAP in 1971. The territorial development of this municipality has been the subject of many studies from different perspectives [24-35] given its relevance in the state context and in the Autonomous Community of the Canary Islands itself.

The shaping of the Maspalomas-Costa Canaria tourist destination began in a regulatory context of scarcity of General Urban Planning Plans that allowed a detailed and rational planning of the territory, in which the Law of Centers and Areas of National Tourist Interest of 1963 was introduced in the only legal instrument for certain local operators to be integrated into the tourism development process. This law was intended to promote land occupation and accommodation offering in coastal areas under the assumption that the greater the number of tourist beds available, the greater the return on investment, based on a so-called theoretical annual growth rate of visitors (as stated in the aforementioned $1963 \mathrm{Law}$ ). In this way, the territorial development of tourism was projected as an essential economic activity that produced different synergies and activated other sectors such as real estate-construction and services, hotels, transport, and commerce. As a result of the above, capital was mobilized and many urban plans were undertaken to provide the corresponding regulatory umbrella for new land uses, with the subsequent urban planning classification of agricultural land. This fact led to an exacerbated process of land classification in the islands known as "touristic", which resulted in more than 250 Plans being approved in the Canary Islands between 1970 and 1975 [36].

All this generated a substantial growth of the tourist offering through the massive, anarchic, opportunistic, and extensive approval of Partial Plans with little or no territorial organization or coordination (Figure 1). Thus, the land legislation in force at that time proved to be inoperative, limiting itself to forming a mere regulatory framework of reference for the rapid conversion of rustic land into urban land for development, but which lacked sufficient controls on its appropriate development. In this way, the urban planning instruments were designed with the intention of favoring the indiscriminate urban classification of the land in order to promote the process of obtaining fictitious income from the land in the short term, with no investment other than the cost of carrying out the urban projects.

\subsection{Supervening Obsolescence and the Consequent Residentialization Process}

Since the first 40 bed-places created in San Bartolomé de Tirajana from 1964 to 1979, in which the existence of 62,022 bed-places is confirmed, over 866 hectares were affected by the different Partial Plans that were developed in the municipality and on which practically all the tourist micro destinations of the municipality were created (Figure 2). In all cases, the various conservation and maintenance actions carried out on their structures proved insufficient to allow them to keep minimum levels of competitiveness $[37,38]$ required in such a dynamic market as tourism; competitiveness understood in a broad sense that is incorporated into a sustainable development model [39,40]. 

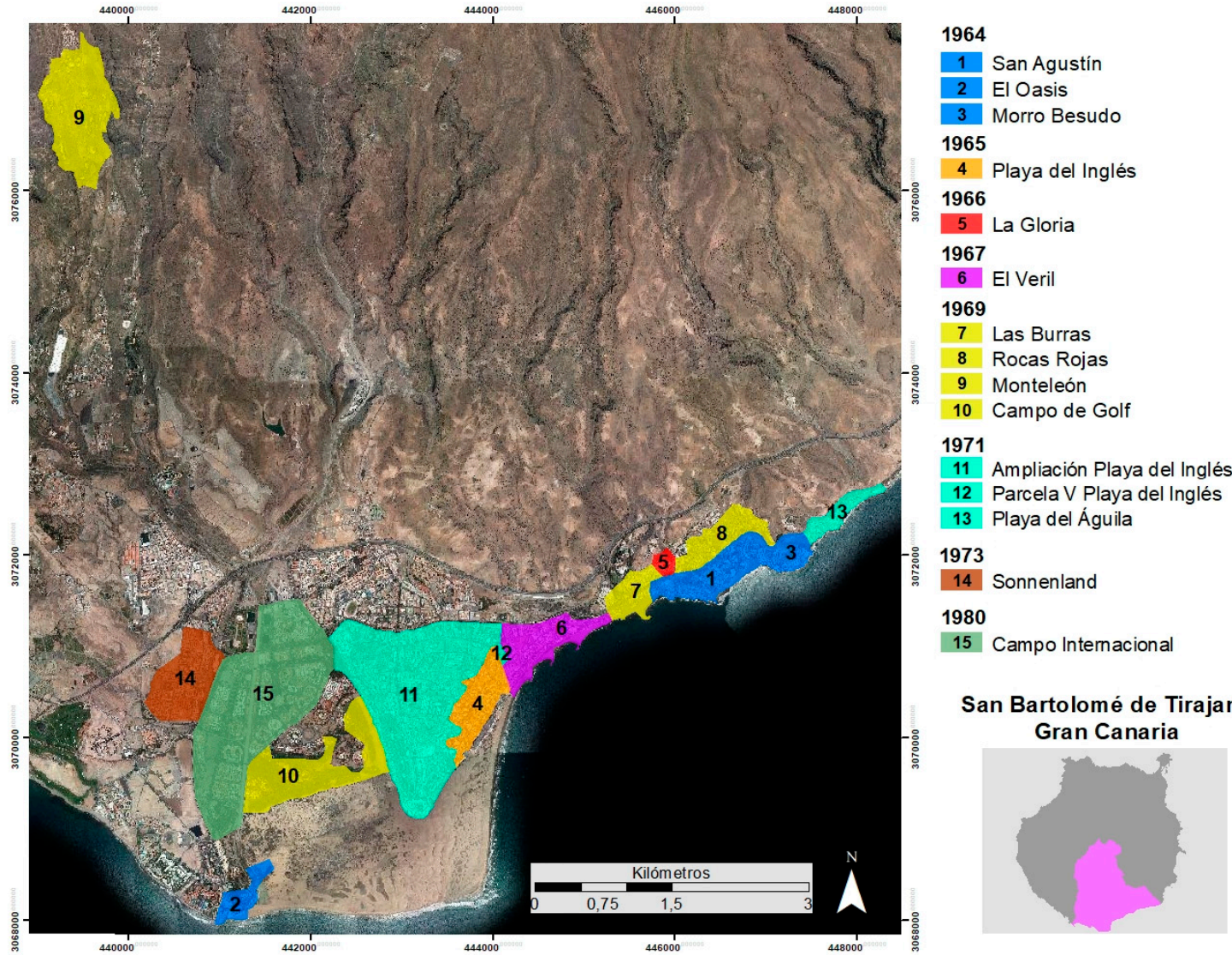

San Bartolomé de Tirajana Gran Canaria

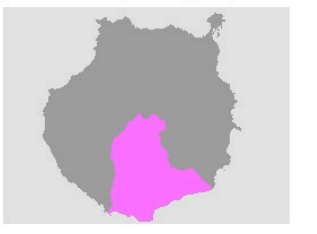

Figure 1. Chronology of events of the Partial Plans in San Bartolomé de Tirajana. Period 1964-1980. Source: Own elaboration.

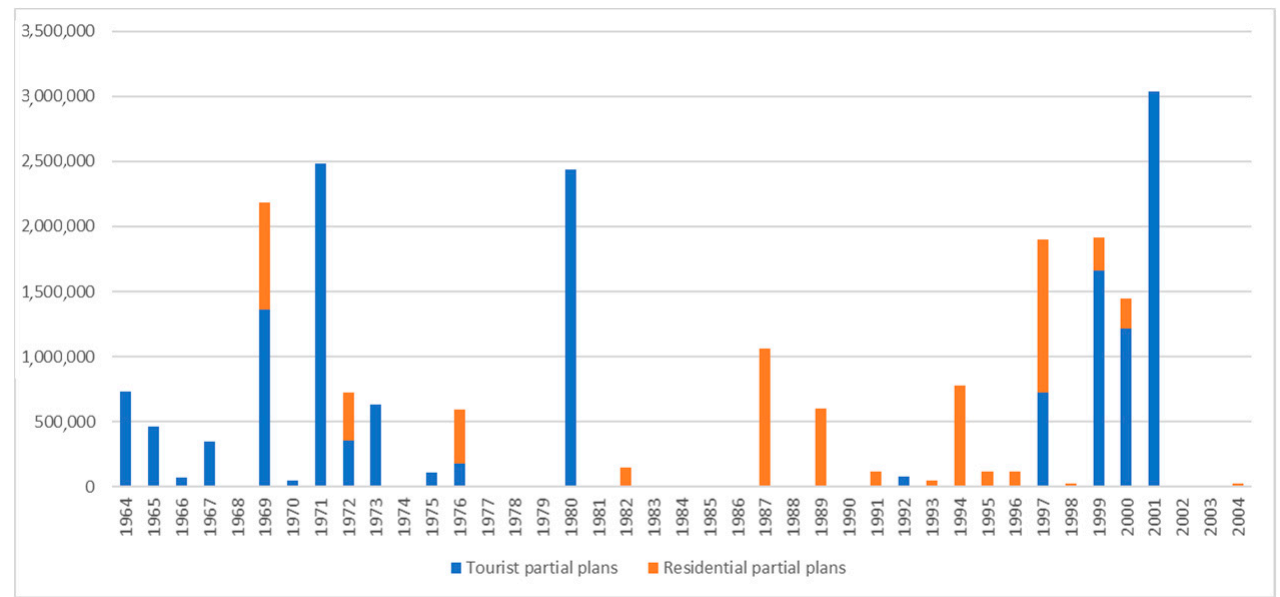

Figure 2. Residential and tourist partial plans of San Bartolomé de Tirajana by years of final approval and surface area (Hectares). Period 1964-2004. (Source: Own elaboration).

Despite what has been said, the occupancy levels obtained through the strategy mentioned above guaranteed a profitability that covered operating costs at least and, in the best case, allowed certain minor maintenance and decoration works to be carried out that justified a certain level of satisfaction even in the most saturated areas [41]. However, profit margins continued to shrink with the further impact on the availability of economic funds that could be used for the partial and/or total modernization, improvement and qualification of tourism facilities, equipment and services, that suffered a general obsolescence (Figure 3). 


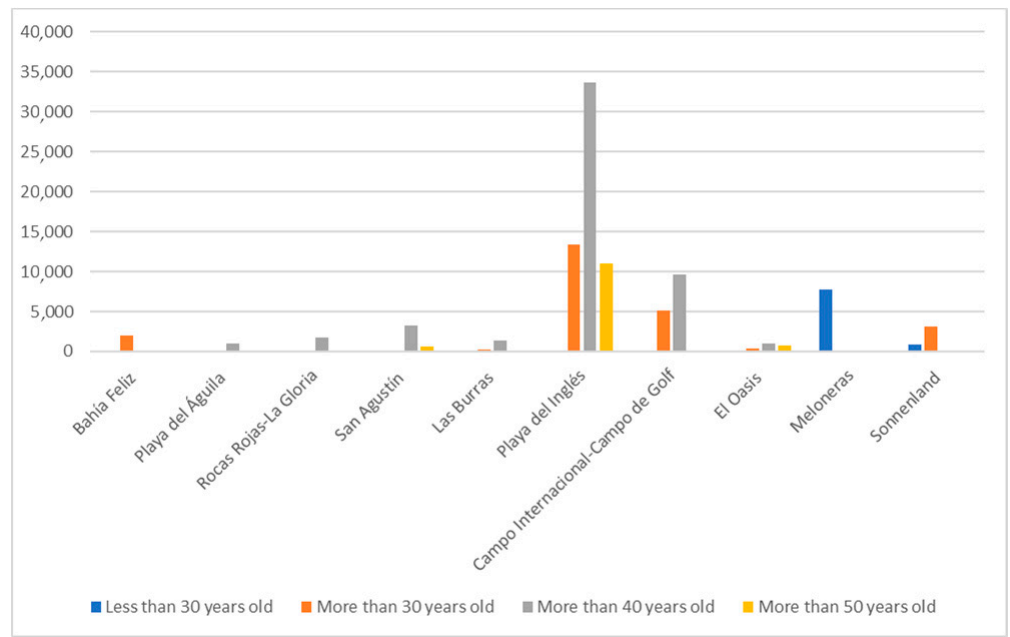

Figure 3. Age of the accommodation offering by territorial tourist micro destinations in San Bartolomé de Tirajana. (Source: Own elaboration).

In addition, the aforesaid process of shaping the Maspalomas-Costa Canaria destination fully explains the high density level of the different micro destinations mentioned above, but it is Playa del Inglés that has the highest rate with 153.64 tourist bed-places per hectare, followed by Bahía Feliz-Playa del Águila (87.03 bed-places per hectare), as shown in Table 1.

Table 1. Densification level by micro destinations in San Bartolomé de Tirajana 2019.

\begin{tabular}{cccccc}
\hline Tourist Pieces & Area & Ha. & Bed Places & Densification (\%) & Establishments \\
\hline Bahía Feliz/Playa del Águila & $456,624.88$ & 45.66 & 3974 & 87.03 & 12 \\
\hline $\begin{array}{c}\text { San Agustín/Rocas } \\
\text { Rojas-La Gloria }\end{array}$ & $871,001.79$ & 87.10 & 5463 & 62.72 & 22 \\
\hline Las Burras & $301,148.48$ & 30.11 & 1981 & 65.78 & 19 \\
\hline Playa del Inglés & $3,077,337.73$ & 307.73 & 47,279 & 153.64 & 230 \\
\hline $\begin{array}{c}\text { Campo Internacional/Campo } \\
\text { de Golf/Oasis }\end{array}$ & $3,191,067.50$ & 319.11 & 9335 & 29.25 & 38 \\
\hline Meloneras & $1,703,251.87$ & 170.33 & 10,805 & 63.44 & 16 \\
\hline Sonnenland & $759,656.13$ & 75.97 & 6479 & 85.29 & 17 \\
\hline
\end{tabular}

Source: Gran Canaria Tourist Board. Own elaboration.

The information above, shows how the age and deterioration of the accommodation offering, together with its non-hotel accommodation modality and the high density level, conditioned the constant residentialization process (i.e., the conversion of tourist residences into conventional residences, either for permanent or temporary use or to incorporate it into the market through other rental systems) that affected the municipality of San Bartolomé de Tirajana [42-44] and which is a characteristic feature of mature coastal destinations [45-48].

Residentialization causes different conflicts between tourist and residential activity, highlighting those referring to the maintenance of common areas and the distribution of expenses, those related to compliance with tourist regulations that residents are reluctant to, deterioration of the image of actual buildings and the diversity of façades and balconies for both uses, the difficult coexistence of the activities of both, etc. Three main players are involved in all of these issues: The public administration, the owners and tourism entrepreneurs who need to develop a joint strategy to ensure the survival of all the interests at stake [49] to also prevent the deterioration of the image of a destination where residential and tourist uses converge (Table 2). 
Table 2. Degree of residentialization and tourist use by territorial tourist micro destinations in San Bartolomé de Tirajana (\%).

\begin{tabular}{ccc}
\hline Tourist Pieces & Residentialization (\%) & Tourist Use (\%) \\
\hline Bahía Feliz & 23.02 & 76.98 \\
\hline Playa del Águila & 39.11 & 60.89 \\
\hline Rocas Rojas-La Gloria & 28.52 & 71.48 \\
\hline San Agustín & 15.89 & 84.11 \\
\hline Las Burras & 30.41 & 69.59 \\
\hline Playa del Inglés & 24.11 & 75.89 \\
\hline Campo Internacional-Campo de Golf & 25.94 & 74.06 \\
\hline El Oasis & 0.00 & 100.00 \\
\hline Meloneras & 0.00 & 100.00 \\
\hline Sonnenland & 37.81 & 62.19 \\
\hline
\end{tabular}

Source: Gran Canaria Tourist Board. Own elaboration.

\subsection{The Urban-Tourist Saturation of Playa del Inglés}

The formation of the urban layout in the Maspalomas-Costa-Canaria area took place in the period from 1965 to 1979 after the approval of successive and unconnected partial plans, which shaped a morphologically heterogeneous area, basically in Playa del Inglés area (Figure 4). The referred Partial Plans were those of Playa del Inglés (1965), El Veril (1967), Ampliación de Playa del Inglés (1971), Parcela V (1971) and Playa del Inglés-Anexo II (1976, although finally approved in 1997 with the PGOU (General Urban Planning Plan).

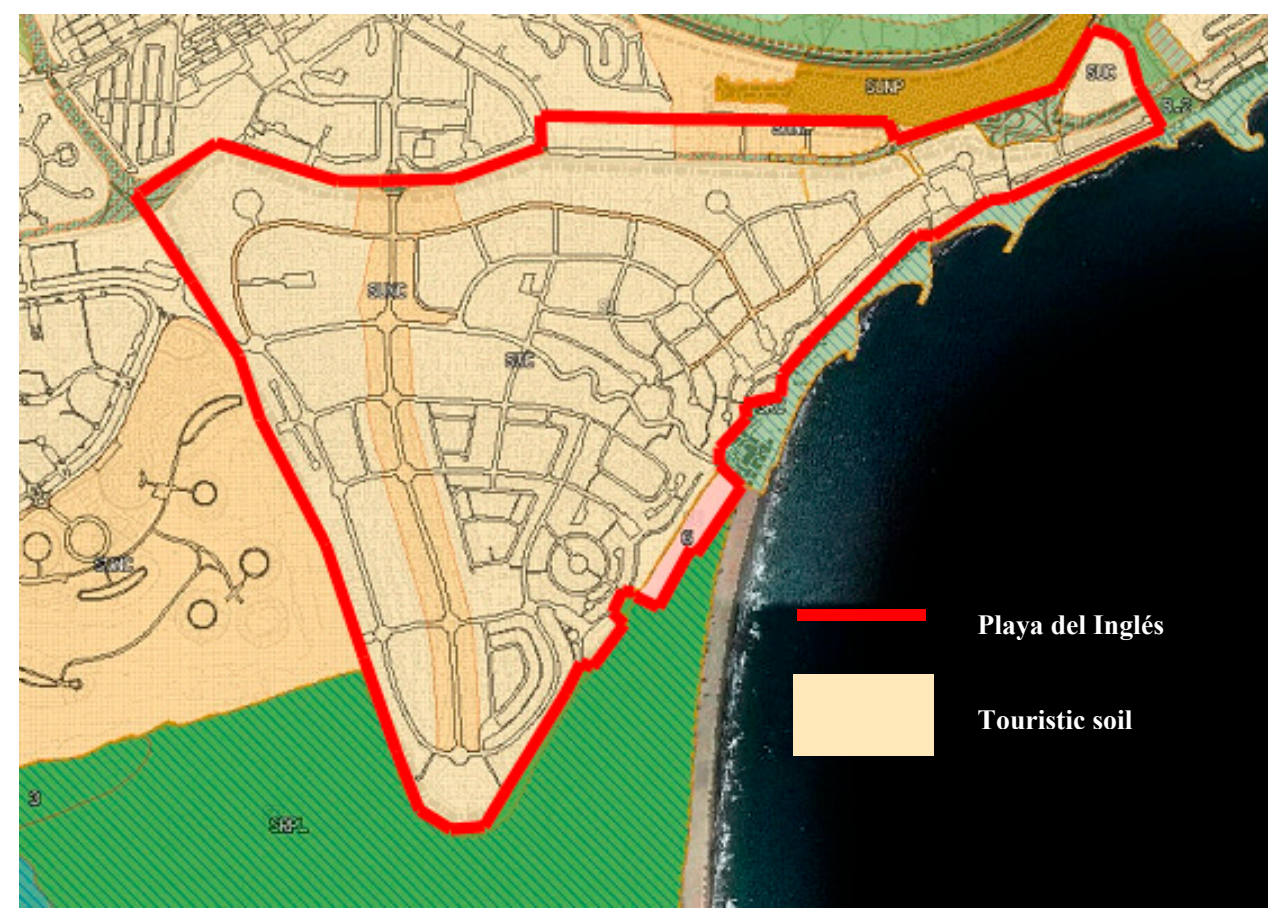

Figure 4. Classification of the land in the area of Playa del Inglés. (Source: GRAFCAN. Government of the Canary Islands. Own elaboration.).

In Gran Canaria in 2019 there were 208 hotel accommodations with 63,795 bed-places, and 6491 non-hotel accommodations with 97,375 bed-places (TURIDATA-Ministry of Tourism of the Canary Islands Government). The distribution by classification and category in the municipality of San 
Bartolomé de Tirajana, according to the Gran Canaria Tourist Board itself, determined that non-hotels represented $50.08 \%$ and $49.92 \%$ referred to hotels. Of the total non-hotels (40,157 bed-places), $27.85 \%$ are one-key establishments, $52.25 \%$ are two-key establishments, $15.20 \%$ are three-star (or three-key) establishments and 3.0\% are four-star (or four-key) establishments. As for the hotel selection, $57.12 \%$ are four-star establishments, $25.01 \%$ are three-star, $15.8 \%$ are five-star, $1.6 \%$ are two-star and $0.45 \%$ are five-star Grand Luxury. Since 2015, pursuant to Decree 113/2015 of 22 May, this includes holiday homes in the non-hotel modality, which together with the villas, emblematic houses and rural houses only have a single category. This type only represents $1.69 \%$ of the non-hotel variety in San Bartolomé de Tirajana but its concentration in the micro destination of Playa del Inglés is almost $60 \%$ (Table 3). This area also accounted for $45.26 \%$ of the total accommodation offering in Gran Canaria and $43.50 \%$ of the total number of overnight stays on the island in 2019 (Gran Canaria Tourist Board, 2019 Tourism Statistics by Area).

Table 3. Accommodation offering by modality and category, per Territorial Tourist Micro Destination in San Bartolomé de Tirajana 2019. (Source: Gran Canaria Tourist Board. Own elaboration.).

\begin{tabular}{|c|c|c|c|c|c|c|c|c|c|c|c|}
\hline \multirow[b]{2}{*}{ Categories } & \multicolumn{5}{|c|}{ Non Hotels } & \multicolumn{6}{|c|}{ Hotels } \\
\hline & 1 & 2 & 3 & 4 & Cat Única & 1 & 2 & 3 & 4 & 5 & $5 \mathrm{GL}$ \\
\hline Bahía Feliz & 88 & 1218 & 459 & & 6 & & & & 511 & & \\
\hline Playa del Águila & & & 142 & & 2 & & & & & & \\
\hline $\begin{array}{c}\text { Rocas Rojas-La } \\
\text { Gloria }\end{array}$ & 450 & 389 & & & & & & & 900 & & \\
\hline San Agustín & 1269 & 898 & 230 & 80 & 79 & & & 1290 & 1957 & 595 & \\
\hline Las Burras & 91 & 27 & & & & & 527 & & & & \\
\hline Playa del Inglés & 6461 & 13,278 & 3470 & 780 & 51 & & 120 & 6433 & 11,550 & 149 & \\
\hline $\begin{array}{c}\text { Campo } \\
\text { Internacional-Campo } \\
\text { de Golf }\end{array}$ & 641 & 1724 & 1247 & 342 & 28 & & & 348 & 1667 & & \\
\hline El Oasis & 2185 & 3275 & 558 & & 294 & & & 612 & 2927 & 2592 & 181 \\
\hline Meloneras & & & & & 64 & & & & 3352 & 2989 & \\
\hline Sonnenland & & 177 & & & 154 & & & 1329 & & & \\
\hline
\end{tabular}

The current hotel accommodation structure (2020) in the Playa del Inglés sector is made up of 37 establishments of different ages, categories, and characteristics, with a total of 19,505 hotel bed-places and 9250 accommodation units (Gran Canaria Tourist Board, 2020). The total surface area of the plots occupied by these establishments is $415,912.06 \mathrm{~m}^{2}$, which, in a detailed analysis, shows a high-level densification with 468.96 bed-places/hectare in this specific area.

A high-level density seems to be inherent to the urban layout itself [50]. But if the urbanization is based on tourist activity and, therefore, destined for leisure and rest, high density can become a characteristic that worsens the perception of the destination and the visitors' own experience, because it also projects an image of low-quality urban space [51].

This issue can be aggravated when conflicts arise between the different authorized uses in a specific area and which in the case in question seem logical when residential and hotel uses converge, causing the contradiction of the leisure/rest binomial, which is very common in mature coastal destinations, and attached to a clear impairment of buildings, which as previously mentioned, is explained by the absence of investment in major rehabilitation or renovation actions. In addition, the atomized ownership of a significant number of accommodation establishments (basically non-hotel establishments) do not have the means to carry out the abovementioned actions and require public policies to encourage these tasks in order to support competitiveness in a sustainable development framework [52].

In the total of the Playa del Inglés sector, the gross density is 153.64 bed-places/ha (out of 47,279 bed-places), excluding those that were lost when converted to residential use (7464 since 2009). 
This figure comes from the agglutination of accommodation establishments that incorporate a high net density. This same situation is what produces a noticeable lack of open spaces, green areas and public services and facilities in the Playa del Inglés micro destination in relation to the tourist buildings in the area, which are practically limited to the promenade, some pedestrian routes and various parking spaces. The rest of the land is for residential tourism use and only has a few commercial facilities (Figure 5).

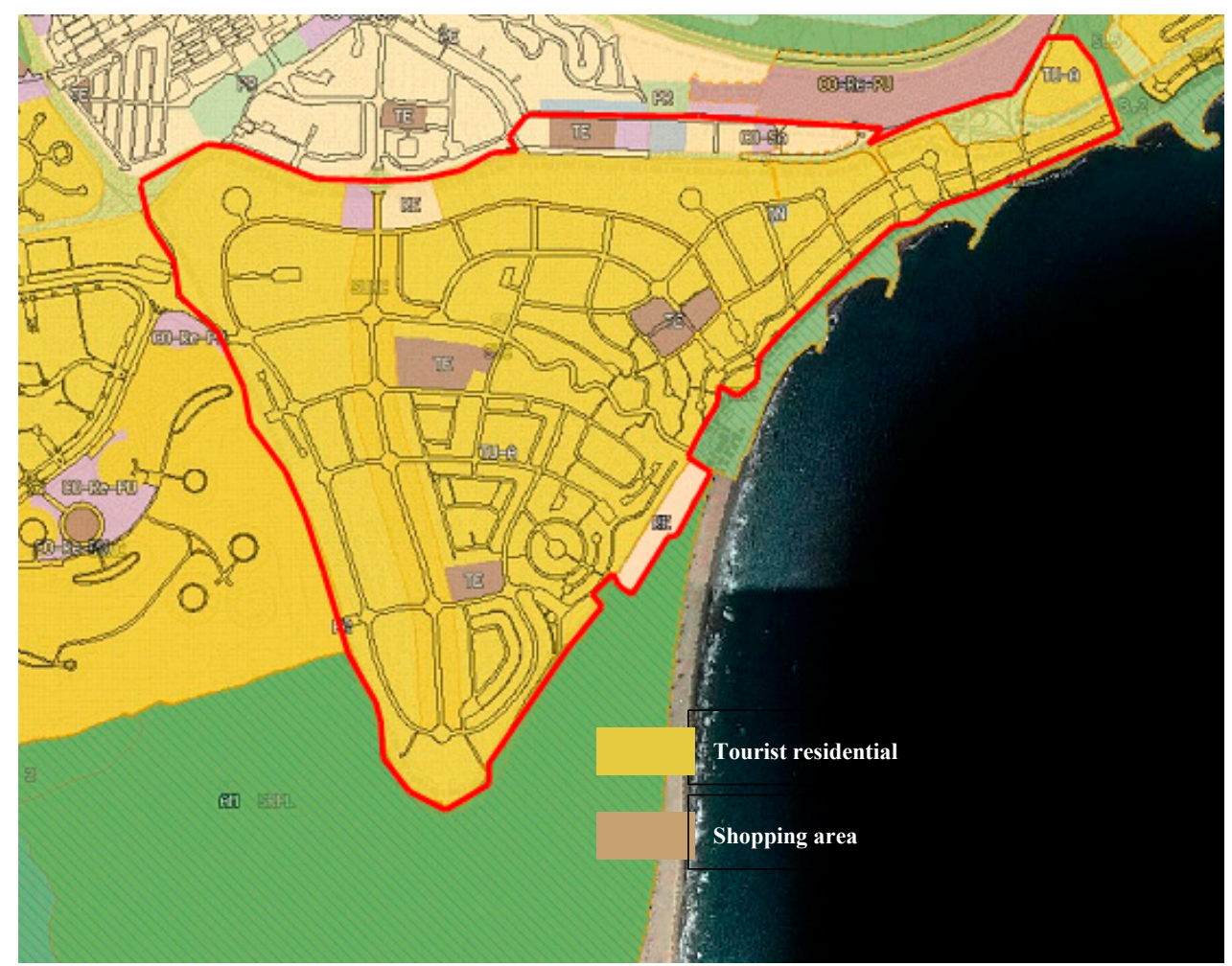

Figure 5. Classification of land in the area of Playa del Inglés (Source: GRAFCAN. Government of the Canaria Islands. Own elaboration.).

\section{Case Study Methodology}

The chosen methodology to undertake this research is the Case Study. In a qualitative way and from a discriminated sample of the population under study, the case analysis allows us to obtain relevant information by contrasting the data obtained, in order to offer a theory that allows increasing the scientific research framework on the subject we have chosen.

According to several authors, Case Study consist in a methodology of empirical enquiry [53-56] using appropriate qualitative techniques based on the real context study, using multiple sources of evidence with an essentially inductive approach and partially deductive [57].

Yin provides 4 Case Study basic designs, which results from a combination of 2 characteristics, depending on whether if it is single Case Study design or if it is a multiple-case study design which describes a holistic case study design with multiple units of analysis also referred as embedded case study can be chosen.

In addition, depending upon the overall objective of the research, Yin distinguishes between 3 Case Study types: (1) Descriptive; that provides a comprehensive overview of the analysis object and study the phenomenon in relation to the real context; (2) exploratory: That allows to discover aspects and questions that determine the viability of investigation procedures or the research itself and analyses a situation about which there is no well-defined theoretical framework (pilot-research) and (3) explanatory; address the cause-effect relationships, the reasons why certain events are produced. On the other hand, Villareal [58] adds a fourth Case Study type to the Yin classification, depending on 
the research specific aim; (4) illustrative, that shows the most competitive companies management practices. Furthermore, regarding to this classification, Gummesson [59] considers that such categories cannot be understood on an isolated way, given that exploratory and descriptive Case Studies could serve to create a theory; moreover, descriptions could be explanatory.

Total of selected Case Studies amounted to 5 out of a sample of 17, previously analyzed. Criteria used to select the sample are closely related to corporate structure, accommodation modality, category and amount of the investment made. In addition, priority was to select cases presenting them as renovation process models undertaken and results obtained.

The data collection process was carried out via in-depth personal interviews with those tourist accommodation managers who had led the renovation processes. These interviews followed a common list of questions (Supplementary Materials) to establish a comparative analysis of the data obtained in every selected case based on the questions and objectives of inquiry. Likewise, review of the administrative files and consultation process involving tourism experts were key to provide a complete information on undertaken projects, with quantitative and qualitative elements, essential to provide rigor to the individualized study.

In terms of studied reference variables, these have been category, rooms, hotel beds (before and after the refurbishment), staff modifications, year of construction, type of property, renovation characteristics (types and areas) and its purpose, initial budget and type of urban incentive used.

\section{Results}

The different elements chosen to assess the potential of the actions undertaken in the renewal processes studied are related to profitability, positioning and prestige online, with the limitations in the information that the establishments themselves provide when it comes to results that affect their income statement.

The different magnitudes studied have been assessed, those offered by the establishments and others that have been deduced, both before and after the renovation process.

Case 1 concerns the Santa Monica Suites Hotel (Figure 6). It is an establishment that, taking advantage of the benefits offered by the PMMs and the owner's "brave" strategic decision, opting for the change from non-hotel modality to hotel modality (four-star Grand Luxury). The following was analyzed sequentially: Development of the building, the decision-making process of the Community of Property Owners regarding the renovation process, the investment project and its departmental implementation, the staff's situation during the closure of the establishment and the execution of the works, the administrative route followed by the proceeding, the incentives used in its renovation and the results obtained once it was reinserted into the tourism market through the new form of management adopted.
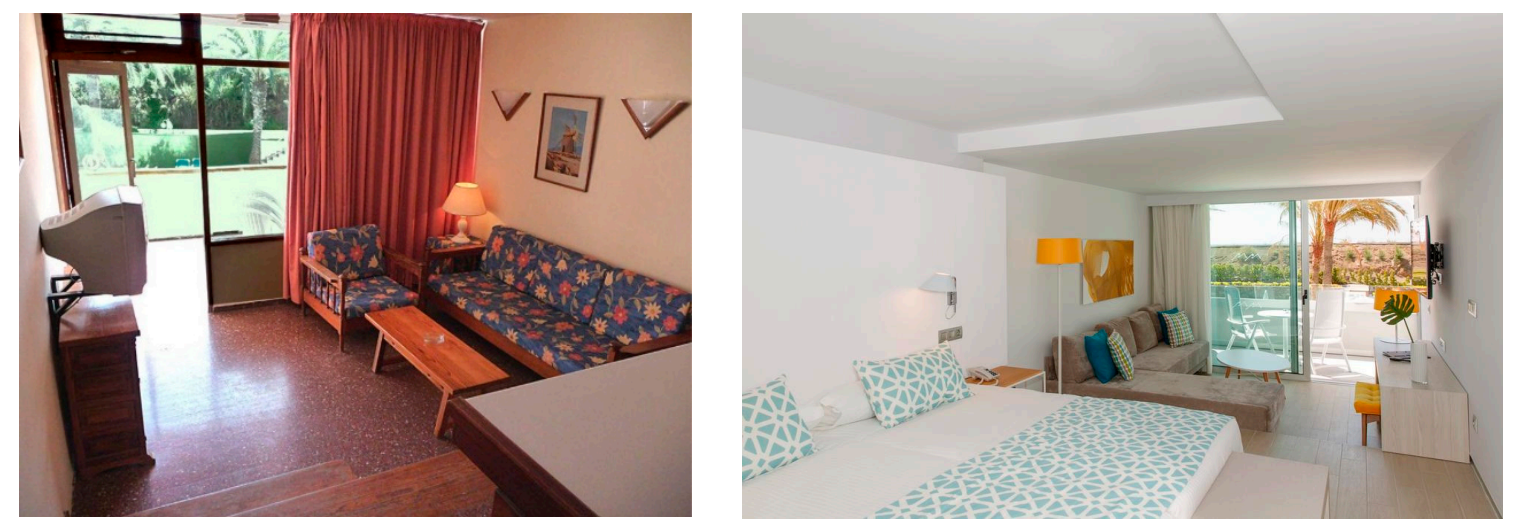

Figure 6. Santa Mónica Suites Hotel before (left) and after (right) the refurbishment (Source: Santa Mónica Suites Hotel). 
The ownership atomized in 110 owners over the 188 properties that make up the building and the existing background in the decision making process within the Community of Property Owners, are elements that add value to the process of renovation and requalification of the Santa Monica Suites Hotel and that becomes a model for the originally non-hotel establishments.

In addition, the location adjacent to a special nature reserve (Dunas de Maspalomas) is a major tourist attraction, making this building in a Landscape-Hotel [60], given its great landscape, geological, botanical and fauna interest in the Canary Islands.

In 2008, Gran Canaria Tourist Board launched a project in cooperation with the local College of Architects in order to provide incentives for renovation projects in different touristic establishments (non-hotels) of the coast of Gran Canaria, financing initial projects. Santa Mónica Apartments owner's community had the opportunity to participate in this initiative, although declined to participate. But Santa Mónica Apartments owner's community decided to support the building renovation and in January 2009 contracted the design of an internal reform basic project. The purpose was transforming the building into a 4-star hotel. This solution was put on hold, being agreed with Thomas Cook Tour Operator the conversion in a 3-Key Apartment. Despite this, Santa Monica Interior Reform Project finally aimed at transforming the building into a 4-star hotel. In December 2013, Santa Mónica Apartments owner's community approved the agreement to renovate the building by a qualified majority.

Notwithstanding the above, some owners expressed serious doubts about the success of the project and its legality, which were resolved by the architect, from a technical point of view. The first alternative referred to a 3-star hotel, rejecting other proposals deemed "excessively luxurious". As in other owner's community, the difficulty was largely due on the obligation of all the owners to assume the costs of the reform and in the possibility of staying outside the project.

The owner's community crucial meeting was held in Jun 2014; approved the agreement at transforming the building into a 4-star hotel. Finally, the category was upgrade to 4 stars superior hotel, in line with the original project drawn up and marketing strategy that it was intended to be carried out. Work began in April 2015, which meant to close the doors to the public, approving funding via Tour Operator.

After 4 years Santa Mónica Suites Hotel opening, the evidence is conclusive. Concerning human resources, staff has increased to 86 employees, of which $80 \%$ are permanent staff and the wage bill accounts for approximately $23 \%$ of gross production. Likewise, prices have increased to 186 euros per night in low season and 220 euros per night in high season, with occupancies around $80 \%$ on average per year. There has also been a slight modification in terms of sales channels: While in low season it is $75 \%$ through tour operators and $25 \%$ through direct sales, in high season it is $82 \%$ through tour operators and $18 \%$ direct sales. Finally, production has increased to $300 \%$ and the yield has risen to approximately $45 \%$ (Table 4 ).

In 2018, 2019 and 2020, Santa Mónica Suites Hotel is ranked in number 4 of all the hotels in Playa del Inglés in Trip Advisor ranking, at the same time 9.3 in Booking (with the recognition Traveller Review Awards 2019 and 2020) and it is classified as fantastic (9.3/10) in ReviewPro. The Hotel has received Tui Top Quality Award (one of the 250 best hotels around the World in 2018 and one of the 100 best hotels around the World in 2019) and Holiday Check 2018, 2019 and 2020 award (as a consequence of obtaining 98\% favorable opinions from 1212 and 5.7/6). It has also received the Sunny Heart Silver Winner as one of the best hotels of 2018 by Thomas Cook users and the TUI Holly 2019 and 2020, as one of the most values hotels of the World.

Case 2 concerns the Hotel Bohemia Suites \& Spa, which experienced a thorough renovation process, increasing the category from 4-star hotel to 5-star hotel, in the adults-only sector and with the novelty that, against the stimulus that could be obtained more places, it reduced accommodation units and places, incorporating also an emblematic architectural element for a restaurant in the structure of the building that is configured as an added value to the establishment's own services aimed at a segment with high purchasing power (Figure 7). 
Table 4. Santa Mónica Suites Hotel economic data before and after renovation.

\begin{tabular}{|c|c|c|c|}
\hline & & $\begin{array}{c}\text { Before the } \\
\text { Refurbidhment }\end{array}$ & $\begin{array}{c}\text { After the } \\
\text { Refurbidhment }\end{array}$ \\
\hline \multicolumn{2}{|l|}{ Category } & 1 Key Apartment & 4-Star Superior Hotel \\
\hline \multicolumn{2}{|l|}{ Rooms } & 178 & 188 \\
\hline \multicolumn{2}{|l|}{ Hotel Beds } & 534 & 564 \\
\hline \multirow{2}{*}{ Staff } & Permanent & 36 & 69 \\
\hline & Temporary & 0 & 17 \\
\hline \multicolumn{2}{|c|}{ Staff/production costs } & $25 \%$ & $23 \%$ \\
\hline \multicolumn{2}{|c|}{ Prices per High Season room/night } & $74 €$ & $220 €$ \\
\hline \multicolumn{2}{|c|}{ Low season } & $48.5 €$ & $186 €$ \\
\hline \multirow{2}{*}{$\begin{array}{l}\text { Marketing } \\
\text { channels }\end{array}$} & $\begin{array}{c}\text { Tour } \\
\text { operators/OTAS }\end{array}$ & $90 \%$ & $\begin{array}{l}\text { High season: } 82 \% \\
\text { Low season: } 18 \%\end{array}$ \\
\hline & Direct sales & $10 \%$ & $\begin{array}{l}\text { High season: } 75 \% \\
\text { Low season: } 25 \%\end{array}$ \\
\hline \multicolumn{2}{|c|}{ Approx. production $(€)$} & $3,370,000.00$ & $10,110,000.00$ \\
\hline \multicolumn{2}{|c|}{ Return/production } & $35 \%$ & $45 \%$ \\
\hline
\end{tabular}

Source: Own elaboration.
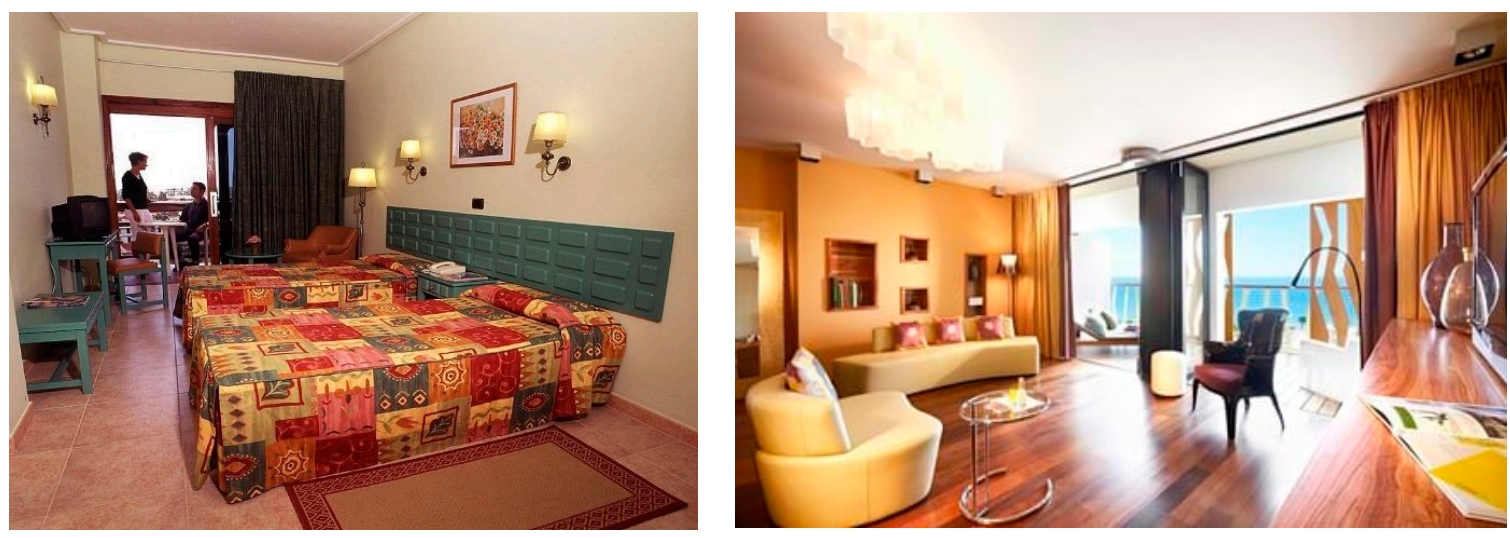

Figure 7. Hotel Bohemia Suites \& Spa before (left) and after (right) the refurbishment (Source: Hotel Bohemia Suites \& Spa).

Since it opened to the public in 1971, the Apolo Hotel had not undergone any kind of refurbishment beyond the daily maintenance of the facilities. The first refurbishment was carried out in 2001 (30 years after opening), with a project to renovate the bathrooms. The major works license was obtained on 2 May 2001, but there is no record of the completion certificate.

This same configuration of the Apolo Hotel in height and having passed the first 40 years since its implementation, made the structure to have significant shortages in habitability and/or energy aspects, that also meant an opportunity to proceed to solve the loss of competitiveness of the establishment and its repositioning in new markets by means of architectural innovation actions [61].

First contribution of this case is linked to the adaptation to a 5-star hotel that was undoubtedly a quality leap of predictable consequences. The resizing of the hotel, reducing the number of accommodation units (from 134 to 67) and bed-places (from 219 to 115), even reducing the surface area for rooms (from $2722.50 \mathrm{~m}^{2}$ to $2441.93 \mathrm{~m}^{2}$ ) and increasing the average surface area per room (from $23.67 \mathrm{~m}^{2}$ to $37.93 \mathrm{~m}^{2}$ ), made it possible to incorporate two premium suites of $105.00 \mathrm{~m}^{2}$ each, 3 junior suites of $70.80 \mathrm{~m}^{2}$ and 24 suites of $47.06 \mathrm{~m}^{2}$. 
Secondly, the incorporation of a panoramic restaurant (called " $360^{\circ}$ ") on its rooftop was a highly attractive element that targeted customers who are not staying in the establishment itself for its gastronomic variety (approximately 70\%), and due to the uniqueness of its design and location has a tremendous potential to transmit and promote images and values of that part of the island [62]. Throughout this process, the renovation of the 8th floor of the building deserves a special section in this study for two specific reasons; firstly, because it greatly modified the general structure of the building and provided it with a space that made this establishment peculiar and emblematic, and the $360^{\circ}$ Restaurant, which lets diners enjoy one of the most privileged views of the entire Playa del Inglés area, while also creating a highly demanding gastronomic variety and, secondly because it took advantage of the building and buildable area incentives that the PMM allowed for this specific purpose.

The owner's latest novel initiative for the hotel is to focus on the "Adults Only" segment; this theme positions the Bohemia Suites \& Spa Hotel in a market area shared with 17 other establishments in San Bartolomé de Tirajana, although it is the only 5-star "Adults Only" establishment in Playa del Inglés, which is undoubtedly a clear commitment to diversify its services, opting for demand segments with greater purchasing power. In short, the Bohemia Suites \& Spa Hotel opted to reinvent itself towards a product with a highly innovating capacity [63] and make its economic continuity viable in a strategy that also significantly lowered the density of occupation of the plot [64]. This theme was not only focused on identifying the hotel differently, its facade, interior or exterior, the rooms or the restaurant, the decoration or the staff's clothing; all of this was a result of the renovation process, but also in an attempt to direct its strategy towards its "Adults Only" guests, with obvious distinctive features in the way it provides its services. That strategy was highly innovative because Hotel Bohemia Suites \& Spa was the first Adults Only (100\%) Hotel in Gran Canaria. The increase in all service standards, the change of its morphology providing it with a unique element on the hotel's roof and its own gastronomic variety have objectively produced positive effects that have had consequences on elements such as the professional positioning and valuation of the establishment, staff, prices, greater independence in the marketing channels and the staff production cost. The Bohemia Suites \& Spa Hotel has certainly improved its competitiveness substantially in an area of special intensity and densification such as Playa del Inglés.

The Bohemia Suites \& Spa Hotel is currently part of the Design Hotels AG corporation, a Frankfurt Stock Exchange-listed company that provides hospitality services to a network of over 300 independent small boutique and luxury hotels in over 50 countries around the world; it is a selected collection of privately owned and operated hotels, each considered a totally unique creative expression. Design Hotels ${ }^{\mathrm{TM}}$ brings together hotels that reflect the vision of a passion for hospitality that is genuinely culturally rooted and in cutting-edge design and architecture. In addition, Design Hotels ${ }^{\mathrm{TM}}$ offers its members customized B2B services, including global launch campaigns, sales representation, revenue management, strategic marketing, public relations and branding. In Spain there are only 21 hotels integrated into this company, only 2 of which are on the Canary Islands, and both are located on the island of Gran Canaria.

The Bohemia Suites \& Spa Hotel currently accumulates the Travellers' Choice ${ }^{\mathrm{TM}}$, Trip Advisor ${ }^{\circledR}$ awards for 2019, 2015 and 2016 as one of the 25 most romantic hotels in Spain and boasts a Certificate of Excellence (14th Luxury Hotel in Spain) in its Hall of Fame 2019. It also holds the Best for Romance Europe and the Mediterranean awards by Condé Nast Johansens for 2017 and 2018. In addition, the 360 Restaurant has been awarded for being the Best Hotel Restaurant on the Canary Islands in 2018, by the Top 10 Awards "Qué bueno Canarias Heineken". And the Hotel received the "InnoBankia" award as the "Best Tourism Company" in 2019", which distinguishes companies that carry out innovative initiatives and projects in this field and was granted by Bankia, La Provincia and Diario de Las Palmas. And in 2018 the "Atelier Cocktail Bar" received the award for the best Hotel Bar in Europe by the Tales of the Cocktails Foundation. In 2019, the Hotel was classified as Excellent by TripAdvisor and is ranked 3rd out of the 134 hotels in Playa del Inglés. It was rated as Fantastic in Booking with a score of 
9.1. Trivago rated it as Excellent with a score of 9.4 and it was also recognized by this portal as one of the 10 designer hotels in Spain during 2016.

Likewise, prices have increased to 260 euros per night in low season and 340 euros per night in high season, with occupancies around $86 \%$ on average per year. There has also been a slight modification in terms of sales channels: $50 \%$ through tour operators and 50\% through direct sales. Finally, production has increased to $290 \%$ and the yield has risen to approximately $29 \%$ (Table 5).

Table 5. Hotel Bohemia Suites \&Spa economic data before and after renovation. (Source: Own elaboration (2020).).

\begin{tabular}{cccc}
\hline & & $\begin{array}{c}\text { Before the } \\
\text { Refurbishment }\end{array}$ & $\begin{array}{c}\text { After the } \\
\text { Refurbishment }\end{array}$ \\
\hline Category & 4-Star Hotel & 5-Star Hotel \\
\hline Rooms & 120 & 67 \\
\hline Hotel Beds & Permanent & 240 & 134 \\
\hline Staff & Temporary & 40 & 70 \\
\cline { 2 - 4 } & Staff/production costs & 30 & 20 \\
\hline \multicolumn{2}{c}{ Prices per High season room/night } & $100 €$ & $38 \%$ \\
\hline \multicolumn{2}{c}{ Low season } & $140 €$ & $260 €$ \\
\hline Marketing & Tour operators/OTAS & 90 & $340 €$ \\
\cline { 2 - 4 } channels & Direct sales & 10 & $50 \%$ \\
\hline Approx. production (€) & $2,500,000.00$ & $7,200,000.00$ \\
\hline Return/production & $20 \%$ & $29 \%$ \\
\hline
\end{tabular}

Finally, cases 3, 4 and 5 includes three non-hotel establishments, with different dimensions and accommodation capacity, which undertook important renovation processes and which, while remaining in the aforementioned modality, allowed them an increase of category and to optimally reposition themselves in their respective markets and geographical areas. There are three models that are repeated in the ten tourist pieces of Maspalomas-Costa Canaria, which are located specifically in the areas of Morro Besudo, San Agustín and Playa del Inglés (three of the areas with the highest level of obsolescence in the municipality and where the residentialization processes were more pronounced); an accommodation modality that has been secularly denounced for its own Generation characteristics.

The non-hotel establishments "El Yate", "Buganvilla" and "El Palmar" (with small, medium and large capacity and volumetry respectively) underwent the same gradual deterioration process, being built in a similar period (in the late 1960s) and with similar property characteristics. In these three studied cases, the volume of investment and the incentives used were diverse, but the successful outcome of all the processes is coincidental.

Three events marked the beginning of the El Yate rehabilitation project; first, the requirement that San Bartolomé de Tirajana Council makes to the establishment to proceed to underpin of the structure to prevent its fall dated December 2006, that can give an idea of the deep status of deterioration of the building for which the drafting of a technical report on the state of the building and the proposal of repair works is commissioned. In second place was the change of ownership in October 2012 and the third was the creation of the exploitation owner's community, a figure that acted as a catalyst for the renovation initiative (Figure 8). 

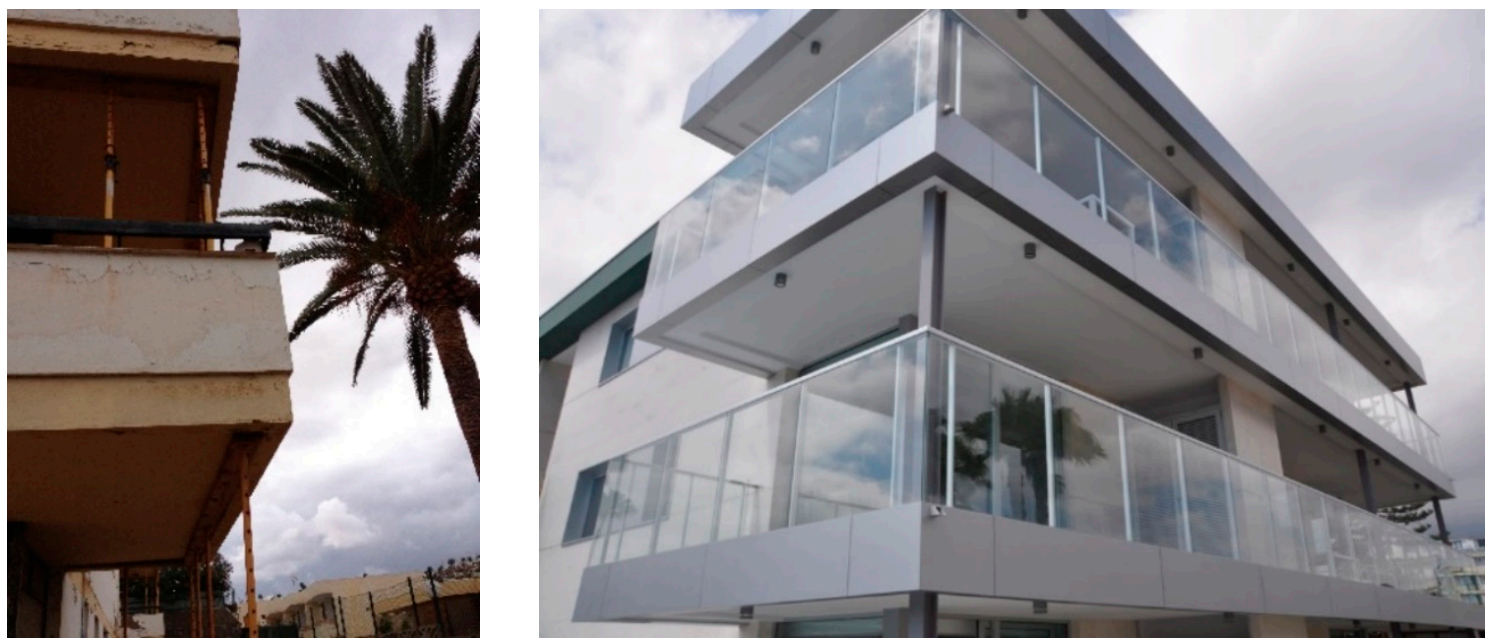

Figure 8. El Yate before (left) and after (right) the refurbishment (Source: El Yate Apartments).

Buganvilla Apartments renovation process was launched at the owner's initiative (only 3) who decided to renovate the facilities, taking advantage of the privileged location next to the avenue and San Agustín Beach, recovering a restaurant closed years ago and incorporating some energy efficiency measures and a gym (Figure 9). Building license was obtained in October 2013. The refurbishment work had a budget of $689,193.98$ euros. This project did not contain any changes to the building parameters, rooms, or bed places on a plot of land of 2633.11 square meters. The authorization for phase II was requested in January 2014 and incorporated, as a strategic element, the restaurant with 189.93 square meters that the establishment had already had, with chill-out treatment and can be closed by secured glass panels. The solar panels, the renovation of the fencing and the terrace were also incorporated. The budget for this phase was of 292,000.00 euros.
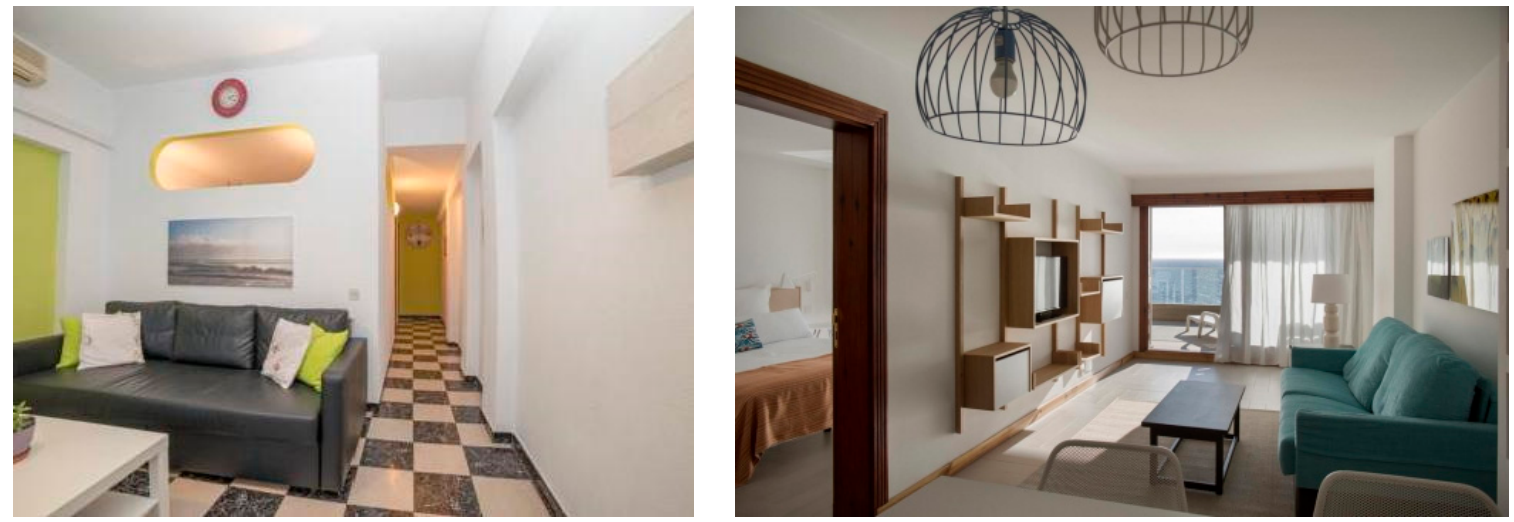

Figure 9. Buganvilla before (left) and after (right) the refurbishment (Source: Buganvilla Apartments).

Finally, El Palmar Apartments was built at the beginning of the seventies and initially had 56 rooms. It was a 4 -storey apartment block $\left(688.80 \mathrm{~m}^{2}\right.$ each floor) and 14 rooms per floor. The reception is located at ground level that also housed the water tank and the installations room. Building originally had another construction of $154.20 \mathrm{~m}^{2}$ destined to a warehouse area, lingerie, changing rooms, facilities, etc.

It is not trivial issue to mention that the property is centralized in a family business and, therefore, decision-making process seems easier, basically when facing a renovation so deep as in this case, in opposition to the problems of the atomization of the property in another non-hotel establishments with a wide range of interests. 
The planned investment amounted to 1,931,285.44 euros, of which 55\% were earmarked for integral renewal. The total number of bed places was 56 , increased by $50 \%$ for taking advantage of Law 2/2013 and 25\% for upgrading category (Figure 10).
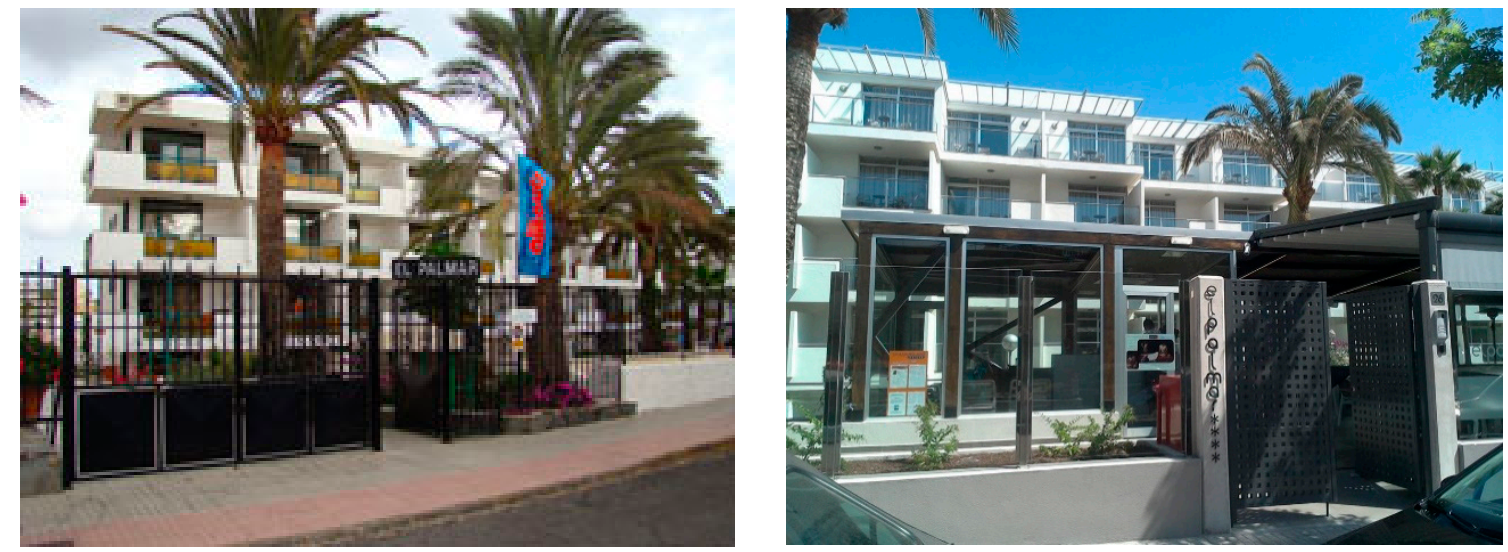

Figure 10. El Palmar before (left) and after (right) the refurbishment Source: El Palmar Apartments.

Currently, El Yate Apartments has a price range from 94.00 euros to 179.00 euros per night (average rates). On TripAdvisor is number 5 of this kind of in San Agustín area; 91\% of their opinions are excellent and very good. It is classified as "Exceptional" on Booking, with a score of 9.5. Average annual occupation is around $90 \%$ throughout the year.

Buganvilla Apartments is the best rated establishment in San Agustín, with an excellent rating of 9.1 and special recognition in 2018. On Booking it has a Fantastic rating with a score of 9.2 and in Adults Only category on TripAdvisor it is listed as the No. 1 accommodation in San Agustín and has Certificate of Excellence. Also, in Holiday Check it appears as an Adults Only establishment with a score of 5.7 out of 6 .

El Palmar is rated Very Good and has a score of 8.0 on booking. The same on TripAdvisor, Very Good and 4.0 (out of 5), is number 65 of the 134 establishments in Playa del Inglés. On Holiday Check has $76 \%$ positive opinions and a score of 4.4 (Table 6).

Table 6. Magnitudes of cases analyzed before and after renovations in non-hotel establishments.

\begin{tabular}{lccc}
\hline \multicolumn{1}{c}{ Magnitudes } & EL Yate & Buganvilla & EL Palmar \\
\hline Tourist piece & Las Burras & San Agustín & Playa del Inglés \\
\hline $\begin{array}{l}\text { Current percentage via } \\
\text { web }\end{array}$ & $20 \%$ & $46 \%$ & $100 \%$ \\
\hline $\begin{array}{l}\text { Current percentage via } \\
\text { platforms (OTAs) }\end{array}$ & $80 \%$ & $54 \%$ & 16 \\
\hline $\begin{array}{l}\text { Current number of } \\
\text { employees (permanent) }\end{array}$ & 2 & 10 & 2 \\
\hline $\begin{array}{l}\text { Current number of } \\
\text { employees (temporary) }\end{array}$ & 1 & 1 & \\
\hline $\begin{array}{l}\text { Former number of } \\
\text { employees (permanent) }\end{array}$ & 0 & 0 & 2014 \\
\hline $\begin{array}{l}\text { Former number of } \\
\text { employees (temporary) }\end{array}$ & 0 & 2013 & \\
\hline \begin{tabular}{l} 
Year of refurbishment \\
\hline
\end{tabular} & 2013 & 10 & \\
\hline
\end{tabular}


Table 6. Cont.

\begin{tabular}{|c|c|c|c|}
\hline Magnitudes & EL Yate & Buganvilla & EL Palmar \\
\hline State of the renovation & Completed & Completed & Completed \\
\hline $\begin{array}{l}\text { Approximate } \\
\text { investment initially } \\
\text { planned }\end{array}$ & $1,000,000$ & 200,000 & $4,000,000$ \\
\hline $\begin{array}{l}\text { Investment finally } \\
\text { made }\end{array}$ & $1,200,000$ & $1,600,000$ & $4,300,000$ \\
\hline Type of investment & Private (Bank Loan) & Private & $\begin{array}{l}\text { Bank Loan and Subsidy } \\
\text { (ERDF) }\end{array}$ \\
\hline $\begin{array}{l}\text { Priority objective of the } \\
\text { works in the } \\
\text { establishment }\end{array}$ & $\begin{array}{l}\text { Increasing category; } \\
\text { improving quality and } \\
\text { image; incorporating } \\
\text { new services and } \\
\text { equipment; changing the } \\
\text { product or business } \\
\text { model; complying with } \\
\text { current regulations; } \\
\text { undertaking accessibility } \\
\text { actions } \\
\text { Increasing category; } \\
\text { modernising decoration; } \\
\text { improving the main } \\
\text { indicators of the tourism } \\
\text { business and business } \\
\text { profitability. }\end{array}$ & $\begin{array}{l}\text { Increasing category; } \\
\text { improving quality and } \\
\text { image; incorporating } \\
\text { new services and } \\
\text { equipment; changing the } \\
\text { product or business } \\
\text { model; adapting it to } \\
\text { customers with higher } \\
\text { purchasing power; } \\
\text { attracting new types of } \\
\text { customers; modernising } \\
\text { decoration; improving } \\
\text { the main indicators of } \\
\text { the tourism business and } \\
\text { business profitability; } \\
\text { surviving the crisis. }\end{array}$ & $\begin{array}{l}\text { Increasing category; } \\
\text { improving quality and } \\
\text { image; incorporating } \\
\text { new services and } \\
\text { equipment; changing the } \\
\text { product or business } \\
\text { model; adapting it to } \\
\text { customers with higher } \\
\text { purchasing power; } \\
\text { attracting new types of } \\
\text { customers; complying } \\
\text { with current regulations; } \\
\text { undertaking accessibility } \\
\text { actions; modernising } \\
\text { decoration; improving } \\
\text { the main indicators of } \\
\text { the tourism business and } \\
\text { business profitability; } \\
\text { surviving the crisis. }\end{array}$ \\
\hline
\end{tabular}

Refurbishment: Includes small-scale works and aesthetic modernization. Renovation: An in-depth change of the less durable elements (systems, flooring, finishes, indoor and outdoor carpentry, sanitary ware and others) was undertaken. Comprehensive renovation (covering over $90 \%$ of the establishment).
Renovation: An in-depth

change of the less durable elements (systems, flooring, finishes, indoor and outdoor carpentry, sanitary ware and others) was undertaken.

Comprehensive renovation (covering over $90 \%$ of the establishment).
Rehabilitation: Conservation, maintenance and decoration (it was increased from 56 to 77 apartments, a restaurant, gym, spa and solarium with views were built).

\begin{tabular}{lccc}
\hline $\begin{array}{l}\text { Hotel Beds before the } \\
\text { modernization }\end{array}$ & 36 & 80 & 112 \\
\hline $\begin{array}{l}\text { Hotel Beds after the } \\
\text { modernization }\end{array}$ & 42 & 80 & 154 \\
\hline $\begin{array}{l}\text { Accommodation units } \\
\text { before the } \\
\text { modernization }\end{array}$ & 18 & 40 & 56 \\
\hline $\begin{array}{l}\text { Accommodation units } \\
\text { after the modernization }\end{array}$ & 12 & 40 & 77 \\
\hline $\begin{array}{l}\text { Percentage of } \\
\text { establishment affected } \\
\text { by the action }\end{array}$ & 100 & 90 & 100 \\
\hline
\end{tabular}


Table 6. Cont.

\begin{tabular}{ll}
\hline \multicolumn{1}{c}{ Magnitudes } & \multicolumn{1}{c}{ EL Yate } \\
\hline & \\
& $\begin{array}{l}\text { Rooms/accommodation } \\
\text { units; public or common } \\
\text { areas; floor corridors; } \\
\text { maintenance area and } \\
\text { technical area; }\end{array}$ \\
Areas where the actions & $\begin{array}{l}\text { administration and } \\
\text { management area; } \\
\text { have been undertaken } \\
\text { outdoor façade } \\
\text { elements/open spaces, } \\
\text { gardens/sports } \\
\text { areas/pool/s area, } \\
\text { solarium. }\end{array}$
\end{tabular}

Rooms/accommodation units; public or common areas; floor corridors; administration and management area; gardens/sports areas/pool/s area, solarium.
Buganvilla

EL Palmar

Rooms/accommodation units; public or common areas; floor corridors; restaurants, dining room, bars and kitchens; maintenance area and technical area; administration and management area; outdoor façade elements/open spaces, gardens/sports areas/pool/s area, solarium, spa centres, casinos, game rooms, gymnasium, multipurpose rooms.

\begin{tabular}{|c|c|c|c|}
\hline $\begin{array}{l}\text { Environmental } \\
\text { sustainability } \\
\text { improvements }\end{array}$ & $\begin{array}{l}\text { Installation of renewable } \\
\text { energies. Bioclimatic } \\
\text { architecture techniques. }\end{array}$ & $\begin{array}{l}\text { Energy consumption } \\
\text { efficiency systems. } \\
\text { Programmes and devices } \\
\text { for controlling and } \\
\text { saving electrical energy: } \\
\text { Installation of renewable } \\
\text { energies. At present, } \\
\text { attempts are being made } \\
\text { to replace chlorine in } \\
\text { swimming pools and } \\
\text { pesticides in gardens. }\end{array}$ & $\begin{array}{l}\text { Energy consumption } \\
\text { efficiency systems. } \\
\text { Programmes and devices } \\
\text { for controlling and } \\
\text { saving electrical energy: } \\
\text { Installation of renewable } \\
\text { energies; } \\
\text { low-consumption LED } \\
\text { lighting. }\end{array}$ \\
\hline $\begin{array}{l}\text { Changes in the } \\
\text { business model }\end{array}$ & & $\begin{array}{l}\text { Theming/specialization } \\
\text { of accommodation: } \\
\text { "Only adults" segment. } \\
\text { Design of new products } \\
\text { and generation of } \\
\text { experiences. }\end{array}$ & $\begin{array}{l}\text { Design of new products } \\
\text { and generation of } \\
\text { experiences. }\end{array}$ \\
\hline $\begin{array}{l}\text { Changes in corporate } \\
\text { management }\end{array}$ & $\begin{array}{l}\text { Implementation of } \\
\text { marketing techniques, } \\
\text { new distribution } \\
\text { channels and } \\
\text { accommodation booking } \\
\text { management. } \\
\text { Implementation of } \\
\text { strategies and techniques } \\
\text { to optimise profitability: } \\
\text { Revenue, prices } \\
\text { (Revenue Management), } \\
\text { of profits (Yield } \\
\text { Management), etc. }\end{array}$ & $\begin{array}{l}\text { Implementation of } \\
\text { marketing techniques, } \\
\text { new distribution } \\
\text { channels and } \\
\text { accommodation booking } \\
\text { management. } \\
\text { Implementation of } \\
\text { strategies and techniques } \\
\text { to optimise profitability: } \\
\text { Revenue, prices } \\
\text { (Revenue Management), } \\
\text { of profits (Yield } \\
\text { Management), etc. }\end{array}$ & \\
\hline $\begin{array}{l}\text { Improved } \\
\text { communications/ } \\
\text { marketing/new } \\
\text { technologies }\end{array}$ & $\begin{array}{l}\text { Renewal of the } \\
\text { website/booking engine. } \\
\text { Renewal of the brand } \\
\text { and corporate image. }\end{array}$ & $\begin{array}{l}\text { Renewal of the } \\
\text { website/booking engine. } \\
\text { Renewal of the brand } \\
\text { and corporate image. }\end{array}$ & $\begin{array}{l}\text { Renewal of the brand } \\
\text { and corporate image. }\end{array}$ \\
\hline
\end{tabular}


Table 6. Cont.

\begin{tabular}{|c|c|c|c|}
\hline Magnitudes & EL Yate & Buganvilla & EL Palmar \\
\hline $\begin{array}{l}\text { Impact on profitability } \\
\text { of the accommodation }\end{array}$ & & $\begin{array}{l}\text { Improvement of the } \\
\text { average accommodation } \\
\text { rate per occupied room } \\
\text { (ADR); pre-performance } \\
\text { ADR: } 45-50 ; \\
\text { post-performance ADR: } \\
\text { 100. Improvement in the } \\
\text { average income per } \\
\text { available room (RevPar) }\end{array}$ & $\begin{array}{l}\text { Improvement of the } \\
\text { average accommodation } \\
\text { rate per occupied room. } \\
\text { Improvement in the } \\
\text { average income per } \\
\text { available room (RevPar) }\end{array}$ \\
\hline $\begin{array}{l}\text { Online reputation on } \\
\text { TRIPADVISOR after } \\
\text { the renovation }\end{array}$ & $\begin{array}{l}\text { Currently } 4.5 \text { (excellent) } \\
37 \text { reviews }\end{array}$ & $\begin{array}{l}\text { Currently } 4.5 \text { (excellent) } \\
223 \text { reviews }\end{array}$ & $\begin{array}{l}\text { Currently } 4.0 \text { (very good) } \\
128 \text { reviews }\end{array}$ \\
\hline $\begin{array}{l}\text { Online reputation on } \\
\text { BOOKING after the } \\
\text { renovation }\end{array}$ & $\begin{array}{l}\text { Currently } 9.6 \\
\text { (exceptional) } 96 \text { reviews }\end{array}$ & $\begin{array}{l}\text { From } 7.8 \text { to } 9.2 \text { (fantastic) } \\
363 \text { reviews }\end{array}$ & $\begin{array}{l}\text { From } 7.8 \text { to } 8.0 \text { (very } \\
\text { good) } 324 \text { reviews }\end{array}$ \\
\hline $\begin{array}{l}\text { Online reputation on } \\
\text { other platforms after } \\
\text { the renovation }\end{array}$ & $\begin{array}{l}\text { Holiday Check 6.0/6 } \\
2 \text { reviews }\end{array}$ & $\begin{array}{l}\text { Holiday Check 5.8/6 } \\
145 \text { reviews }\end{array}$ & $\begin{array}{l}\text { Holiday Check } 4.5 / 6 \\
389 \text { reviews }\end{array}$ \\
\hline $\begin{array}{l}\text { Recognition or award } \\
\text { after renovation }\end{array}$ & TUI and Thomas Cook & $\begin{array}{l}\text { Certificate of excellence } \\
\text { on TripAdvisor and } \\
\text { Booking, best 4-Star } \\
\text { establishment in Gran } \\
\text { Canaria in Apollo for } \\
\text { two consecutive years. }\end{array}$ & \\
\hline $\begin{array}{l}\text { Cost of staff on } \\
\text { production }\end{array}$ & & $\begin{array}{l}\text { Before the Renovation } \\
35 / 38 \% \text { After the } \\
\text { Renovation } 25 \% \text {. }\end{array}$ & $\begin{array}{l}\text { Before the Renovation } \\
60 \% \text { After the } \\
\text { Renovation } 50 \% \text {. }\end{array}$ \\
\hline $\begin{array}{l}\text { Approximate Annual } \\
\text { Production (euros) }\end{array}$ & & & $\begin{array}{l}\text { It has tripled compared } \\
\text { with the time before the } \\
\text { renovation. }\end{array}$ \\
\hline $\begin{array}{l}\text { Approximate return on } \\
\text { production }\end{array}$ & & & $\begin{array}{l}\text { Before the Renovation } \\
10 \% \text { After the } \\
\text { Renovation } 20 \% \text {. }\end{array}$ \\
\hline
\end{tabular}

Source: Own elaboration (2020).

\section{Discussion and Conclusions}

This research focuses on the results achieved through the urban incentives of the public policy on renovation of mature tourist areas on the coast, considering the different types of accommodation in a destination such as Maspalomas-Costa Canaria (in the municipality of San Bartolomé de Tirajana).

We can affirm that because of their location and the nature of their formation, basically in an improvised manner due to the non-compliance and irregular development of planning instruments, with few regulatory controls and through the uncontrolled occupation of the territory, the mature coastal destinations present profound deterioration and obsolescence problems in their public and private infrastructures that directly affect their market positioning and complicate their competitiveness in relation to other competing destinations.

Thus, public administrations that promote policies for the renewal of public and private infrastructures need to rely on all the players involved in tourism activity to reach a consensus on initiatives aimed at renewing and modernizing destinations.

The cross-cutting nature of tourism activity and the involvement that must be shown by all areas concerned, require the promotion of participatory processes for the shaping of renewal strategies, 
modernization and competitiveness, which also requires a reliable, adequate and easily accessible information system for all operators.

We can point out that urban planning incentives are essential instruments for achieving the effectiveness of public policies to renew accommodation in consolidated coastal tourist destinations. These allow requalifying the accommodation offer, increasing the category or changing the modality from a non-hotel to a hotel establishment, and a substantial leap in the qualification that directly improves all the magnitudes of profitability, positioning and prestige of the tourist accommodations subject to renovation. To this end, the rehabilitation and renovation processes of mature coastal destinations must broaden their content and extend beyond the structure itself, addressing the improvement of urban residential-tourist spaces and promoting more "friendly" spaces for coexistence with the territory where they are settled, with the resident population and with the tourist activities themselves, in safer and more accessible environments.

We consider sustainable urban planning would contribute, in conjunction with urban renovation and rehabilitation initiatives, to provide another added value to our mature coastal destinations by anticipating the future trends of the different markets, the upcoming energy requirements and the sensitivity of travelers to different environmental considerations. Therefore, the General Urban Development Plans, together with their own characteristic determinations, should focus on the management elements that allow for the optimization of all their tools and determine all the impacts that their execution may generate with a general approach of sustainability and under a wider perspective of territorial planning, with the acceptance of the Island Urban Development Plans as an instrument of general regulatory structure and the criterion of load capacity as an element to restrict new activities and/or growth.

The experience of San Bartolomé de Tirajana-its generation, deterioration process and renovation initiatives produced-should serve to provide relevant data, in an attempt to teach and convey the changes that have taken place and the consequences of public and private decisions taken under the legal system in each validity period.

The results that can be drawn from this article indicate that from the time a tourist destination becomes stagnant and the accommodation offering becomes obsolete, it is necessary for the public authorities to react by promoting and encouraging extensive and convincing processes for renewal through different initiatives.

It was in this regulatory context that the renovation process of the 5 analyzed cases began, and in the saturating circumstances of the Maspalomas-Costa Canaria area, it was proven that business leadership together with institutional complicity are core elements in strategic decision making, not only from the company's point of view itself but also from the management's point of view of a mature destination that periodically requires "incentive pills" to stimulate repositioning in the market in an efficient management of all resources [65].

The reclassification of the establishments and their repositioning and renovation, the increase in all service standards and the change of their morphology that could be included in the so-called Strategic Sustainability [66], have objectively produced positive effects that have had consequences on elements such as the professional positioning and valuation of the establishment, staff, prices, greater independence in the marketing channels and the staff production cost. The 5 analyzed cases certainly improved its competitiveness substantially in an area of special intensity and densification such as Maspalomas-Costa Canaria.

\section{Future Lines of Research}

The contributions that possibly make up the elements that justify the chosen line of research and that help to explain the relevance of urban incentives in the building rehabilitation strategy in mature coastal destinations have been made. However, any research work, in addition to clarifying the elements that make up its core interest, raises new questions and opens up spaces of uncertainty that must be addressed in order to confirm and project the information displayed here. 
The case study methodology used could become a data bank of all the experiences carried out so far in the Canary Islands under the PMMs and until the courts issue their decision, in order to accurately evaluate the urban development incentives policy incorporated in this instrument, in each of the destinations benefiting from such schemes and whether the projects implemented have had an impact on the competitiveness of each of these tourism products and geographical areas.

Given the state of obsolescence of the different tourist destinations and micro destinations of the Canary Islands and the high number of establishments, susceptible to rehabilitation and renovation processes, considering the judicial drift of PMMs, another challenge is to propose new legislative planning alternatives that, within the legal and constitutional framework and complying with the processing required by procedural regulations, to provide new incentives to promote and encourage processes of urban-tourist renovation in mature coastal destinations in the Canary Islands.

Finally, taking the cases studied as a reference, another line of research could focus on making a current economic projection of the cost of renovation per accommodation unit in establishments that have not undergone any renovation process or of a certain size. The aim is to find out the approximate renovation costs per establishment and, as a result of the renovation processes, its effects on the workforce and foreseeable results in different economic magnitudes.

\section{Limitation of Research}

This section explains the main limitations that have emerged throughout the research and that have been accommodating the methodology used and the results obtained, which forces them to be considered in order to optimize their use.

Firstly, with regard to tourism statistics, the weakness and variety of sources during the 1970s and 1980s show significant differences between the figures for accommodation and tourist arrivals. The historical information obtained from the I.N.E. (National Statistics Institute), studies carried out regionally (private or public) and on the islands, reveal the scarce interest in information systems until the late 1990s, which scarcely coincided with the data offered until then; a strategy that was corrected by more rigorous statistical systems from the INE, the Canary Islands Statistics Institute, PROMOTUR and the Tourism Boards themselves.

Secondly, and with regard to the study of specific cases, the business zeal to provide reliable information on its business and management strategy, marketing, prices, products, profitability, results, etc., even success factors, is surprising in a society collapsed by information systems, where not only the administrations are in a position to cross all the available data to plan their activity but also tourism users have the possibility of making their consumption decisions based on it.

In spite of the above, the deduction of the data published on official websites, institutional pages, press articles and OTAs allows us to unravel and complement the information offered on each of the cases studied and to confirm the initial hypothesis.

Supplementary Materials: The following are available online at http:/www.mdpi.com/2071-1050/12/21/8775/s1. The interviews with those tourist accommodation managers who had led the renovation processes followed this common list of questions.

Author Contributions: Conceptualization, J.M.S.D.; methodology, J.M.S.D., T.A.Q., and Y.A.C.; investigation, J.M.S.D., T.A.Q., and Y.A.C.; resources, J.M.S.D.; writing-original draft preparation, J.M.S.D. and T.A.Q.; writing-review and editing, T.A.Q., J.M.S.D., and Y.A.C.; supervision, J.M.S.D. All authors have read and agreed to the published version of the manuscript.

Funding: This research received no external funding. This work has been carried out within the framework of the Research Projects granted by the Ministry of Economy, Industry and Competitiveness, DER 2017-85616-R, under the title: Desmontando la economía colaborativa: Hacia una nueva forma de comercialización de productos y servicios, PI is Professor Inmaculada González Cabrera.

Conflicts of Interest: The authors declare no conflict of interest. The company, selected as case-study, had no role in the design of the study; in the analyses or interpretation of data; in the writing of the manuscript, or in the decision to publish the results. 


\section{References}

1. Simancas Cruz, M.; De Souza Iglesias, A.M.; Núñez Cano, M. La renovación de los espacios públicos de las áreas turísticas consolidadas. In En Destinos Turísticos Maduros Ante el Cambio: Reflexiones Desde Canarias; Universidad, Instituto Universitario de Ciencias Políticas y Sociales: San Cristóbal de La Laguna, Spain, 2010; pp. 183-216.

2. Simancas Cruz, M. Evaluando políticas públicas de renovación de destinos turísticos maduros: El proceso de reconversión turística de Canarias. In Renovación y Reestructuración de Destinos Turísticos en Áreas Costeras: Marco de Análisis, Procesos, Instrumentos y Realidades; Servei de Publicacions: Valencia, Spain, 2012; pp. $163-199$.

3. Vera-Rebollo, J.F.; Rodríguez-Sánchez, I.; Capdebón Frías, M. Reestructuración y competitividad en destinos maduros de sol y playa: La renovación de la planta hotelera de Benidorm. In Proceedings of the XIII Congreso Internacional de Turismo Universidad y Empresa: Renovación de Destinos Turísticos Consolidados, Castellón, Spain, 6-8 May 2010.

4. Simancas Cruz, M.R.; Ledesma González, O. La planificación territorial de la política de renovación de las áreas turísticas maduras. Planes de Renovación, Mejora e Incremento de la Competitividad de Canarias. PASOS Rev. Tur. Patrim. Cult. 2016, 14, 335-352. [CrossRef]

5. Dorta Rodríguez, A. Aproximación al papel de las políticas turísticas en la reestructuración y renovación de los destinos turísticos consolidados: Los casos de Hawai, Miami, Costa británica. Scheveningen, Baleares y Canarias. Cathar. Rev. Cienc. Humanid. 2013, 13, 5-14.

6. Sanabria Díaz, J.M.; Simancas Cruz, M.; Aguiar-Quintana, T. La reconversión de alojamientos turísticos: El caso de Santa Mónica Suites Hotel. In 100 Soluciones a 50 Problemas Para la Gestión Turística de Empresas en Iberoamérica: Manual de Casos Reales; Editorial Síntesis: Madrid, Spain, 2019.

7. Hildenbrand Scheid, A. La política de ordenación del territorio de las comunidades autónomas: Balance crítico y propuestas para la mejora de su eficacia. Rev. Derecho Urbanístico Medio Ambiente 2006, 40, 79-140.

8. Mirallave Izquierdo, V. Consideraciones sobre la reconversión del espacio turístico canario. Cartas Urbanas 2004, 9, 84-93.

9. García Márquez, F. La nueva generación de Directrices Territoriales/Turísticas y la Sostenibilidad: La experiencia canaria. Estud. Turísticos 2007, 172, 89-95.

10. Llorca Afonso, E.; Sosa Díaz-Saavedra, J.A. Procesos de reciclaje aplicados al turismo de masas en el Sur de Gran Canaria. Vector Plus 2009, 34, 65-76.

11. Díaz, E.A.R. Análisis sistemático de las medidas de turismo y sostenibilidad territorial en la Ley 6/2009, de 6 de mayo, de Medidas Urgentes en Materia de Ordenación Territorial para la Dinamización Sectorial y la Ordenación del Turismo. In 10 años de la Ley de Ordenación del Territorio en Canarias; Tirant lo Blanch: Valencia, Spain, 2010; pp. 379-406.

12. Simancas Cruz, M.R. La Moratoria Turística de Canarias: La Reconversión de un Destino Turístico Maduro Desde la Ordenación del Territorio; Servicio de Publicaciones de la Universidad de La Laguna: San Cristóbal de La Laguna, Spain, 2015.

13. Simancas Cruz, M.S. La política canaria de renovación de las áreas turísticas del litoral. In i Existe un Modelo Turístico Canario? PROMOTUR Turismo Canarias: San Cristóbal de La Laguna, Spain, 2016; p. 86.

14. Temes-Cordovez, R. The Renovation of the Touristic Cities in Canary Island. A Considerable Answer for a Mature Destinations. Available online: https://revistas.uva.es/index.php/ciudades/article/view/783/763 (accessed on 10 August 2020).

15. González, P.R.; Turégano, M.A.S. La Reconversión Hotelera en las Regiones Turísticas Españolas. Rasgos y Efectos Generales. Available online: https://iermb.uab.cat/es/altrepublicacion/xi-congreso-espanol-desociologia-madrid-2013-2/ (accessed on 12 August 2020).

16. Villar Rojas, F. Crónica sobre la construcción de un marco legal para la renovación del espacio turístico en Canarias. Práctica Urbanística 2016, 138, 1-14.

17. Jamal, T.B.; Getz, D. Collaboration theory and community tourism planning. Ann. Tour. Res. 1995, 22, 186-204. [CrossRef]

18. Sautter, E.T.; Leisen, B. Managing stakeholders a Tourism Planning Model. Ann. Tour. Res. 1999, 26, 312-328. [CrossRef]

19. Ivars, B.; Josep, A. La política turística. In Estructura Económica del Turismo; En Sáez Cala, A., Martín Urbano, P., y Pulido Fernández, J.I., Eds.; Síntesis Editorial: Madrid, Spain, 2006; pp. 449-486. 
20. Velasco González, M. Gestión de Destinos: ¿Gobernabilidad del Turismo o Gobernanza del Destino? In Simposio Internacional de Turismo y Ocio; ESADE: Barcelona, Spain, 2008; Volume 17.

21. Velasco, M. El papel del conocimiento en los nuevos modelos de gobernanza turística regional y local. Conocimiento, Creatividad y Tecnología para un Turismo Sostenible y Competitive. In Proceedings of the XII Congreso de la Asociación Española de Expertos Científicos en Turismo, Tarragona, Spain, 12-14 December 2010; pp. 131-140.

22. Barbini, B.; Biasone, A.M.; Cacciutto, M.; Castellucci, D.I.; Corbo, Y.A.; Roldán, N.G. Gobernanza y turismo: Análisis del estado del arte. In Simposio Internacional Gobernanza y Cambios Territoriales; Universidad Nacional del Comahue: Pucón, Chile, 2011; pp. 111-125.

23. Fernández, M.C.P.; Fernández, J.I.P. Destinos turísticos. Conformación y modelos de gobernanza. In Estructura Económica de los Mercados Turísticos; Síntesis: Madrid, Spain, 2013; pp. 179-204.

24. Álvarez León, I. The tourist project of the SETAP Group for the International Bid of Ideas for Maspalomas Costa Canaria. In Proceedings of the 6th Conference of the International Forum on Urbanism (IFoU): TOURBANISM, Barcelona, Spain, 25-27 January 2012; International Forum on Urbanism: Delft, The Netherlands, 2012; pp. 1-10.

25. González, C.B.; Colombiani, M.O.; Socorro, J.J.S. Análisis de la situación de la oferta extrahotelera en Gran Canaria. Medidas de tipo legislativo y de gestión para la mejora de su comercialización. Rev. Jurídica Canar. 2011, 20, 85-134.

26. Cáceres Morales, E.; Pescador Monagas, F. Paisaje y urbanización turística: El caso del sur de Gran Canaria. Urban 2001, 6, 15-34.

27. Franco López, P.J.; Mendoza Quintana, A.T. Maspalomas: Las Raíces del Progreso 1964-2004, los Inicios de la Zona Turística, Homenaje a los Pioneros del Trabajo Hostelero. Available online: https://mdc.ulpgc.es/ cdm/compoundobject/collection/mdci/id/1744/rec/4 (accessed on 22 August 2020).

28. Hernández, L.; José, A. Perfil del turismo en el sur de Gran Canaria. In Evolución e Implicaciones del Turismo en Maspalomas Costa Canaria; Hernández, J.A., Parreño, J.M., Eds.; Concejalía de Turismo del Ayuntamiento de San Bartolomé de Tirajana: San Bartolomé de Tirajana, Spain, 2001; pp. 159-169.

29. Hernández, L.; José, Á. Transformación de una gran propiedad agraria en suelo turístico: El ejemplo del sur de Gran Canaria. Tur. Rev. Estud. Tur. Canar. Macaronesia 2010, 2, 23-36.

30. Nadal Perdomo, I.; Guitián Ayneto, C. El Sur de Gran Canaria: Entre el Turismo y la Marginación (The South of Gran Canaria: Between Tourism and Marginalization); CIES: Lanzarote, Spain, 1983.

31. Parreño Castellano, J.M. Características de la oferta turística de Maspalomas Costa Canaria. In Evolución e Implicaciones del Turismo en Maspalomas Costa Canaria; Ayuntamiento de San Bartolomé de Tirajana: San Bartolomé de Tirajana, Spain, 2001; Volume 1, pp. 103-127.

32. Pérez Sosa, I.; Navas Ferrer, T. Evolución histórica de dos destinos turísticos internacionales: Costa Canaria y Costa Brava. ACE 2014. [CrossRef]

33. Santana, T.; Manuel, Á. Políticas públicas de desarrollo, turismo y tecnocracia: ¿ hacia un cambio de paradigma? P3T. Public Policies Territ. 2012, 1, 1-8.

34. Pérez Sosa, I. Maspalomas: Una Mirada a las Políticas de Actuación Turística en Destinos Costeros Maduros. Ph.D. Thesis, Universitat Politècnica de Catalunya, Barcelona, Spain, 2016.

35. Simancas Cruz, M.; Dorta Rodríguez, A.; Dávila Mamely, H. La Licencia Urbanística de Obras Como Indicador de los Procesos de Renovación de los Destinos Turísticos Maduros de Litoral. Boletín Asoc. Geógr. Españoles 2017, 73. [CrossRef]

36. García Barba, F. Panorama sobre la ordenación del territorio en Canarias. Basa 1989, 9, 6-25.

37. Sanabria Díaz, J.M. Gran Canaria tourist competitiveness: Competitor markets behaviour (Tunisia, Turkey and Egypt) and future forecasts. In Proceedings of the IV Spring Symposium on Challenges in Tourism Development (SSTD2019), San Bartolomé de Tirajana, Spain, 6-7 June 2019.

38. Sanabria Díaz, J.M.; León González, C.; Aguiar-Quintana, T. Modernization Plans under the law 2/2013 May, the 29th, on Tourism Renewal and Modernization of the Canary Islands. Requalification as an increment factor of competitiveness: The case of Santa Monica Suites Hotel. In Proceedings of the III International Congress of Tides "Gran Canaria Spring Symposium on Challenges in Sustainable Tourism Development", San Bartolomé de Tirajana, Spain, 7-8 June 2018.

39. Saarinen, J. Critical sustainability: Setting the limits to growth and responsibility in tourism. Sustainability 2014, 6, 1-17. [CrossRef] 
40. Cîrstea, Ş.D. Travel \&Tourism Competitiveness: A Study of World's Top Economic Competitive Countries. Procedia Econ. Financ. 2014, 15, 1273-1280.

41. Simancas Cruz, M.; Peñarrubia Zaragoza, M.P. Analysis of the Accommodation Density in Coastal Tourism Areas of Insular Destinations from the Perspective of Overtourism. Sustainability 2019, 11, 3031. [CrossRef]

42. Huete Nieves, R.; Mantecón Terán, A.; Mazón Martínez, T. ¿ De qué hablamos cuando hablamos de turismo residencial? Cuad. Tur. 2008, 22, 101-121.

43. Huete Nieves, R.; Terán, M.A. La Clave es el Paisaje Explorando Alternativas al Turismo de Masas. Available online: https://www.researchgate.net/publication/320885332_La_clave_es_el_paisaje_Explorando_ alternativas_al_turismo_de_masas (accessed on 10 August 2020).

44. Sanabria Díaz, J.M.; León González, C.J.; Aguiar-Quintana, T. Economic impact of modernization process in private touristic facilities planned in "the plan of the modernization, improvement and increase of the competitiveness of San Bartolomé de Tirajana". In Proceedings of the II International Congress of Tides "Gran Canaria Spring Symposium on Challenges in Sustainable Tourism Development", San Bartolomé de Tirajana, Spain, 18-19 May 2017.

45. Breuer, T. Retirement migration or rather second-home tourism? German Senior Citizens on the Canary Islands. Dedicated to Jürgen Bähr on his 65th birthday. Die Erde Z. Ges. Erdkd. 2005, 136, 313-333.

46. Parreño, C.; Juan, M. Turismo residencial de europeos y consecuencias inmobiliarias en Canarias. In Proceedings of the VIII Coloquio y Jornadas de Campo de Geografía Urbana, Illes Balears, Spain, 19-24 June 2006; Asociación de Geógrafos Españoles: Madrid, Spain, 2006; pp. 383-398.

47. Simancas Cruz, M.R.; Horcajada Herrera, T.; García Cruz, J.I. La modelización territorial de los procesos de residencialidad en áreas turísticas consolidadas de litoral: El caso de Costa Adeje (Tenerife). In Turismo, Urbanización y Estilos de vida: Las Nuevas Formas de Movilidad Residencial; Icaria: Barcelona, Spain, 2009; pp. 315-334.

48. Pavón, E.L.S.; Tabales, A.F. El litoral turístico español en la encrucijada: Entre la renovación y el continuismo. Cuad. Tur. 2010, 25, 185-206.

49. Santana-Jiménez, Y.; Hernández, J.M.; Suárez-Vega, R. Land use conversion from tourist to residential. Curr. Issues Tour. 2019, 22, 1686-1704. [CrossRef]

50. Rodríguez-Rodríguez, Y.; Hernández-Martín, R. Expert Consensus versus Statistical Techniques in the Delimitation of Tourism Destinations. Sustainability 2020, 12, 2540.

51. Simancas Cruz, M.; Peñarrubia Zaragoza, P.; Temes-Cordovez, R.; Horcajada Herrera, T. La transformación de los destinos turísticos en ciudades: Análisis geodemográfico de las áreas turísticas de litoral de Canarias. Rev. Estud. Reg. 2017, 112, 125-152.

52. Saarinen, J.; Rogerson, C.M.; Manwa, H. Tourism and the Millennium Development Goals: Tourism, Local Communities and Development; Routledge: Abingdon, UK, 2013.

53. Yin, R.K. Case Study Research: Design and Methods; Sage: Newbury Park, CA, USA, 1989.

54. Eisenhardt, K. Building theories from case study research. Acad. Manag. Rev. 1989, 14, 532-550. [CrossRef]

55. Coller, X. Estudio de Casos. Centro de Investigaciones Sociológicas. Available online: https: //www.researchgate.net/profile/Xavier_Coller/publication/277718680_Coller_Xavier_2000_Estudio_de_ casos_Madrid_CIS/links/5c138ca9a6fdcc494ff2e48b/Coller-Xavier-2000-Estudio-de-casos-Madrid-CIS.pdf (accessed on 10 August 2020).

56. Villareal Larrinaga, O. La internacionalización de la empresa: El modelo de las diez estrategias. Rev. Int. $2008,67,67-82$.

57. Yin, R.K. Case Study Research: Design and Methods, 2nd ed.; Sage: Newbury Park, CA, USA, 1994.

58. Villarreal Larrinaga, O. Is it desirable, necessary and possible to perform research using case studies? Cuad. Gestión 2017, 17, 147-172. [CrossRef]

59. Gummesson, E. Qualitative Methods in Management Research; Sage Publications Inc.: London, UK, 2000.

60. Huete Nieves, R.; Tros-de-Ilarduya, M. La Valorización de los Espacios Naturales como Pretexto para el Desarrollo Urbanístico en el Sudeste de España. Available online: https://bdigital.uncu.edu.ar/objetos_ digitales/13609/06hueteproyeccion10.pdf (accessed on 10 August 2020).

61. Horrach Estarellas, G. Aprendiendo de la balNearización: Mallorca, un Laboratorio Internacional del Turismo de Masas y de Conformación de los Destinos Maduros Litorales. Ph.D. Thesis, Universitat Politécnica de Catalunya (UPC), Barcelona, Spain, 2016. 
62. Pardo García, S.M. Las Vistas Panorámicas de Núcleos Urbanos: Propuesta Para su Análisis y Aplicación al caso de Andalucía. Ph.D. Thesis, Universidad de Málaga, Málaga, Spain, 2015.

63. Boné Espinosa, D.; Rey García, A.; Fuste Forné, F. Los hoteles temáticos: Un caso descriptivo de creación de experiencias a través de ejemplos singulares españoles. Pap. Tur. 2015, 58, 47-57.

64. Moscardo, G.; Murphy, L. There is no such thing as sustainable tourism: Re-conceptualizing tourism as a tool for sustainability. Sustainability 2014, 6, 2538-2561. [CrossRef]

65. Niñerola, A.; Sánchez-Rebull, M.V.; Hernández-Lara, A.B. Tourism research on sustainability: A bibliometric analysis. Sustainability 2019, 11, 1377.

66. Dunphy, D.; Benveniste, J.; Griffiths, A.; Sutton, P. An introduction to the sustainable corporation. In Sustainability: The Corporate Challenge of the 21st Century; Allen \& Unwin: Sydney, Australia, 2000; pp. 3-18.

Publisher's Note: MDPI stays neutral with regard to jurisdictional claims in published maps and institutional affiliations.

(C) 2020 by the authors. Licensee MDPI, Basel, Switzerland. This article is an open access article distributed under the terms and conditions of the Creative Commons Attribution (CC BY) license (http://creativecommons.org/licenses/by/4.0/). 